\title{
TARIKAT TIJANIYAH DI KALIMANTAN SELATAN
}

\section{Syafruddin*}

\begin{abstract}
Ajaran tarikat Tijaniyah memiliki karakteristik tersendiri dari tarikat lainnya. Di antara karakteristik itu adalah (a) tarikat ini mengambil format baru sebab, Abmad at-Tijani tidak mengharuskan pengikutnya menunjukekan sikeap ketakwaan yang berlebih-lebihan, dan menekankan pada kebaradaan juru syafaat antara manusia dengan Tuban, juru syafaat itu Abmad at-Tijani sendiri serta wiridnya sederbana dan tegas, (b) pengakuan Ahmad at-Tijani mencapai dua kedudukan, yaitu sebagai wali Quthb al-Aqthab dan Khatm al-Waliyah. (c) tarikat ini melarang pengikutnya merangkap keanggotaan dengan tarikat lain, (d) tarikat ini tidak memiliki silsilah, kalaupun ada sillilahnya lebih pendek dari tarikat lain. (e) tarikat ini melarang pengikut merokok karena dianggap najis, dan (f) tarikat ini tampaknya tidak bertentangan dengan syariat Islam.
\end{abstract}

Kata kunci: tarikat Tijaniyah, wirid, zikir

\section{Pendahuluan}

Agama Islam dengan bidang-bidangnya telah melahirkan ilmu-ilmu. Bidang keimanan melahirkan ilmu kalam atau ilmu ushuluddin dengan pembahasan pokoknya tentang keesaan Allah; bidang keislaman melahirkan ilmu fikih dengan pembahasan pokoknya tentang hukum, dan bidang keihsanan melahirkan ilmu tasawuf dengan pembahasan pokoknya tentang kerohanian.

Dalam Alquran dan sunah Nabi terdapat ayat-ayat yang merujuk dan memberi perhatian terhadap masalah kerohanian. Di samping itu Alquran lebih jauh menjelaskan betapa pengalaman kerohanian Nabi ketika bertemu dengan Malaikat Jibril saat berada di Gua Hira di atas bukit Cahaya (Jabal Nur) dan

\footnotetext{
*Penulis adalah dosen tetap Fakultas Dakwah IAIN Antasari Banjarmasin.
} 
ketika Nabi di perjalanan dari Masjid al-Haram di Mekkah ke Masjid al-Aqsa di Palestina (Isra) dan kemudian naik ke langit (mikraj) menyaksikan tanda-tanda kebesaran Tuhan yang agung tak terkira.(al-Isra: 1 dan Najm : 1-18).

Tasawuf dalam perkembangan dan pertumbuhannya dipandang sebagai counter og culture dari perkembangan pemikiran rasional dalam Islam. Pemikiran rasional mendapat dukungan kekuasaan dengan berdirinya kerajaan-kerajaan besar dalam Islam (kerajaan Bani Umayyah dan Bani Abbas). Ajaran tasawuf tersebut awalnya mendasarkan pada perilaku Nabi Muhammad saw., para Sahabat dan Tabiin, yang bersumber dari Alquran dan sunah dengan berpijak pada prinsip-prinsip : zuhud, rida dengan kehidupan sederhana, dan motivasi yang intens terhadap keutamaan tingkah laku. ${ }^{1}$

Pertentangan antara penganut syariat di satu pihak, dan penganut tasawuf di pihak lain, telah terjadi berkepanjangan dan bahkan melelahkan. Masingmasing membenarkan keberagamaannya sendiri dan menyalahkan keberagamaan orang lain. Bentuk-bentuk pertentangan tersebut kadang-kadang tidak dapat dibenarkan begitu saja. ${ }^{2}$ Masalah tersebut juga telah terjadi di Kalimantan Selatan. Tarikat-tarikat yang dianut masyarakat dengan doktrin dan ritualnya yang unik sering menimbulkan konflik di antara umat. Hal ini terjadi karena para ulama yang umumnya ulama fikih dan akidah, sering mencurigai, bahkan mengadakan "penelitian" terhadap kebenaran doktrin dan ritual tarikattarikat tersebut. Dalam kaitan ini bisa dikemukakan beberapa kasus seperti kasus H. Jalaluddin versus H. Saberan Kacil di Banjarmasin, kasus H. Muhammad Noor di Takisung dan kasus Qurtubi di Amuntai. ${ }^{3}$ Ketiga kasus tersebut menurut penilaian masyarakat, mereka telah menyimpang dari syariat dan lebih berorientasi kepada al-wahdah-al-wujudi (tasawuf falsafi).

Pengajian tarikat di Kalimantan Selatan cukup marak, di antaranya adalah kegiatan pengajian yang dilakukan oleh tarikat Tijaniyah, tarikat Naqsyabandiyah, dan tarikat Syazaliyah. Pengajian tarikat tersebut mampu menarik minat masyarakat Islam dari berbagai lapisan, seperti ibu rumah tangga, petani, buruh, pedagang, pegawai negeri, bahkan para guru agama, dari

\footnotetext{
${ }^{1}$ Wahib, Tasawnf dan Transformasi Sosial (Studi Atas Pemikir Tasawuf Hamka). (Surabaya: IAIN Sunan Ampel, 1997), h. 2.

2Zulkifli, Neo Sufisme di Indonesia Pemikiran dan Perkembangannya. (Palembang: Puslit IAIN Raden Fatah, 1997), h. 5.

${ }^{3}$ M.Zurkani Jahja, Syariat, Sufisme dan Tarekat (Refleksi Terhadap Beberapa Kasus di Kalimantan Selatan), (Banjarmasin: IAIN Antasari, 1993), h. 18.
} 
kelas bawah sampai kelas atas, dengan latar belakang dan motivasi yang berbeda-berbeda.

\section{Asal Usul Tarikat Tijaniyah di Kalimantan Selatan}

Tarikat Tijaniyah di Kalimantan Selatan dibawa oleh K.H. Ahmad Anshari anak dari H. Hasan Basri, yang dilahirkan di Kota Banjarmasin Jalan Nagasari pada hari Senin tanggal 11 Nopember 1956.

Pada usia 6 tahun, tepatnya tahun 1962, ia masuk sekolah dasar di SDN Mawar Jalan Cempaka VII dan selesai pada tahun 1969, kemudian melanjutkan ke pesantren Darussalam Martapura atau di Makhad Istidadul Mualimin. Satu tahun kemudian ia dipindahkan ke kelas 2 Tsanawiyah Darussalam. Semenjak itulah ia dibukakan hati oleh Allah bergaul dengan guru-guru tasawuf guna membersihkan batin dan melatih diri agar ingat kepada Allah. Pada usia 13 tahun ia mendapat izin untuk mengamalkan tarikat Syazaliyah dari seorang guru bernama Muhammad Nor yang bertempat tinggal di Dalam Pagar. Tarikat ini diamalkannya selama dua tahun. Kemudian ia masuk ke tarikat Naqsyabandiyah dengan Habib Muhsin bin Ali al-Hindurah asal Sumenep Madura yang kebetulan berada di Banjarmasin.

Pada usia 17 tahun, K.H. Ahmad Anshari melanjutkan sekolah ke Madrasalah Aliyah Darussalam, akan tetapi sebelum menamatkan studinya di Madrasah Aliyah tersebut, tepatnya sedang duduk di kelas 2, ia keluar dari sekolah itu dengan maksud ingin meneruskan studi ke Mekkah al-Mukarramah.

Tahun 1974 Ahmad Anshari mendapat panggilan dari Allah swt untuk melaksanakan rukun Islam kelima dan melanjutkan sekolah di sana selama satu tahun. Sangat disayangkan ia tidak bisa meneruskan sekolahnya dan pulang ke kampung halaman (Banjarmasin), dikarenakan orang tuanya tidak sanggup membiayai. Cobaan ini ia hadapi dengan rida dan hati yang lapang, untuk mengisi kegiatan ia memilih kerja dan mengaji di kampung di samping aktif mengamalkan tarikat Naqsyabandiyah.

Tahun 1976 H. Ahmad Anshari mendapat panggilan Allah untuk kedua kalinya melaksanakan rukun Islam yang kelima, dan meneruskan studinya. Ia belajar di Mekkah selama 20 tahun (sejak 1976 sampai tahun 1995) mempelajari kitab kuning dengan kaji duduk. Studinya cukup berhasil, terbukti ia cukup lancar berbahasa Arab baik nahu maupun syarafnya dan menerjemahkannya ke dalam Bahasa Indonesia.

Tahun 1988 H. Ahmad Anshari pulang ke Indonesia khusus untuk masuk tarikat Tijaniyah. Ia masuk tarikat Tijaniyah kepada salah seorang tokoh 
ulama dan tarikat bernama K.H. Badri Masduqi, karena pada saat itu di Mekkah ia tidak mengetahui dan tidak mendengar adanya tarikat Tijaniyah. Untuk mengetahui itu ia pulang. Setelah masuk tarikat Tijaniyah, ia kembali ke Mekkah.

Pada tahun 1995, H. Ahmad Anshari baru bertemu dengan Syekh Idris al-Iraqi dan berbaiat langsung untuk pengokohan dan pemantapan masuk tarikat Tijaniyah. Pertemuan tersebut tidak direncanakan, karena H. Ahmad Anshari sendiri tidak mengenal Syekh dan di mana tempat tinggalnya.

H. Ahmad Anshari masuk tarikat Tijaniyah dikarenakan adanya mimpi seakan-akan berada di salah satu zawiyah tarikat Tijaniyah. Ia belum pernah belajar maupun mendengar tarikat ini dan diberi sebuah kitab Jawahirul Maani. Kitab ini menjadi pegangan para pengikut tarikat Tijaniyah. Kitab tersebut memuat amalan atau wirid yang cukup sederhana tapi memiliki makna dan manfaatnya sangat luar biasa. Wirid itu memberikan keseimbangan antara istigfar, shalawat dan kalimat tauhid.

Aktivitas H. Ahmad Anshari adalah berkhidmat untuk umat Nabi Muhammad saw, khususnya pengikut tarikat dengan memberikan pelajaran kepada mereka dan sambil mengulang kaji kitab-kitab yang pernah ia pelajari. ${ }^{4}$

Kalau diperhatikan riwayat tarikat Tijaniyah di Kalimantan Selatan, terutama latar belakang pendidikan di bidang tasawuf yang diperoleh $\mathrm{H}$. Ahmad Anshari dari kota Intan Martapura itu merupakan produk orang berilmu agama bagi masyarakat Banjar, di samping didahului dengan masuk dua tarikat (Sazaliyah dan Naqsyabandiyah), wajar saja tarikat Tijaniyah mendapat sambutan di hati masyarakat, sehingga tarikat ini terus berkembang dan tumbuh subur dalam kehidupan mereka. Hasil jerih payah dan kerja keras tanpa pamrih dan ikhlas yang dilakukan $H$. Ahmad Anshari dalam rangka menyebarluaskan ajaran Islam khususnya tarikat Tijaniyah, dapat dilihat dan dirasakan dewasa ini seperti jumlah pengikut berjumlah 15.000 ribu orang dan memiliki 21 majelis taklim.

Melihat kepribadian, pendidikan dan pengalaman dalam bertarikat, $\mathrm{H}$. Ahmad Anshari telah memenuhi kriteria dan persyaratan menjadi seorang mursyid (guru), karena sudah mendapat izin atau berijazah, berarti ia memiliki otoritas serta legalitas kesufian termasuk membimbing, mengayomi, mengawasi serta mengajarkan jalan hidup tasawuf (ajaran tarikat) kepada pengikutpengikutnya. Oleh sebab itu, ia mempunyai tanggung jawab yang cukup berat, diantaranya harus alim, arif, jujur, bijaksana, tawaduk, sabar, dan ahli dalam

${ }^{4}$ Hasil wawancara dengan H. Ahmad Anshari di Banjarmasin. 
memberikan bimbingan kepada pengikutnya baik mengenai amalan-amalan yang akan diamalkan maupun masalah-masalah lainnya seperti cara makan, minum, melarang makan banyak dan lain-lain, pandai menyimpan rahasia, dan tidak sewenang-weang memerintah dan melarang murid-muridnya, serta menyediakan tempat berkhalwat, dan lain-lain.

Silsilah tarikat Tijaniyah yang diterima oleh K.H. Ahmad Anshari adalah dari K.H. Badri Masduqi dari Syekh Idris al-Iraqi dari Syekh Muhammad Hafiz al-Misri dari Sayyid Assyarif Ahmad Sukayrij al-Marakisyi dari Sayyid Assyarif Ahmad al-Nadalawi at-Tijani dari al-Gaust Asshamadaani Sayyidi Assyarif Ali at-Tamasini at-Tijani dari Penghulu seluruh Auliya dari Munriddul Aqwast wal Aqthab Maulana Ahmad bin Muhammad bin Muhammad at-Tijani menerima dari al-Habibul Akzam warasulul akram Muhammad bin Abdillah sallallahu alaihi wa sallam secara yakzhah (dalam keadaan jaga), tidak dalam keadaan tidur dan mimpi. ${ }^{5}$

Sanad yang paling dekat adalah Pertama, K.H. Ahmad Anshari menerima dari al-Muhaddits Syekh Idris al-Iraqi, dari Syekh Ahmad Sukayrij al-Marakisyi dari Ahmad al-Badalawi dari Syekh Sli at-Tamasini dari Syekh Ahmad at-Tijani dari Rasulullah saw secara jaga. Kedua, K.H. Ahmad Anshari menerima dari Syekh Ahmad bin Muhammad Hafiz al-Misri dari orang tuanya, Muhammad Hafiz, dari Syekh Abdul Munin dari Syekh Ali Maharazim dari Syekh Ahmad at-Tijani dari Rasulullah saw.

Dalam mengembangkan tarikat Tijaniyah, K.H. Ahmad Anshari mengangkat muqaddam (pemegang wilayah). Mereka boleh membaiat orang yang ingin masuk tarikat ini. Diantaranya K.H. Suni, salah seorang ulama yang cukup kharismatik di Negara kelahiran tahun 1907, ia masuk tarikat Tijaniyah

${ }^{5}$ Silsilah K.H. Ahmad Anshari itu diambil dari ijazah tarikat Tijaniyah yang ia terima. Persyaratan mendapatkan ijazah tarikat Tijaniyah adalah muslim, mendapat izin kedua orang tuanya, guru yang mentalkinkan harus mendapat izin dari syekh (guru), harus melepaskan wirid tarikat lain, tidak boleh berziarah ke wali baik hidup atau mati, harus mengekalkan salat lima waktu dan syariat lainnya, harus cinta kepada syekh/guru, tidak boleh merasa selamat dari azab Allah, harus melaksanakan wirid sampai akhir hanyatnya, tidak boleh mencaci maki, harus mantap mempercayai keutamaan-keutamaan yang disampaikan kepada syekh, wazifah dan haylalah dilakukan berjamaah, salawat Jauharul Kamal dalam membacanya harus dalam keadaan suci, tidak boleh memutuskan hubungan dengan siapapun, harus menyembunyikan wirid, harus menghormati hubungan nasab dengan guru, harus berbakti kepada orang tuanya, wirid harus dibaca samar dan dihayati serta dilaksanakan dengan duduk kecuali uzur, waktu membaca wirid harus menghadap kiblat, dan tidak boleh kritis terhadap syekh/guru. Lihat, Muhammad bin Abdullah bin Husaini asy-Syafi'i at-Tasfawi At-Tijani, Fathur Rabbani. (Karakasan: Makhad Badri al-Daja al-Islamiyah, t.th), h. 156-158. 
ketika ia naik haji pada tahun 1995 langsung dibaiat oleh Syekh Idris al-Iraqi. Walaupun pada saat itu K.H. Suni ${ }^{6}$ ingin sekali berbaiat dengan K.H. Ahmad Anshari, karena pada saat itu ia masih muda, ia menolaknya untuk membaiat K.H. Suni diserahkan ke Syekh Idris al-Iraqi. K.H. Suni mulai mengembangkan tarikat ini pada tahun 1996. sekitar Negara dan tidak meluas ke daerah lainnya, hal ini kemungkinan ia sudah tua dan uzur. Kedua, Ahmad Nawawi kelahiran Barabai tahun 1959 masuk tarikat ini melalui K.H. Suni tahun 1997 dan tahun 1999 berbaiat dengan K.H. Ahmad Anshari. Ahmad Nawawi diangkat menjadi muqaddam (pemegang wilayah) pada tahun 2000 dan langsung dipercayakan untuk mengembangkan tarikat Tijaniyah kepada masyarakat sekitar dan santrinya. ${ }^{7}$ Ketiga Ibrahim kelahiran Anjir tahun 1966 masuk tarikat Tijaniyah tahun 1997 dan diangkat menjadi muaqaddam/badal tahun 2000 untuk wilayah Anjir Kota Barito Kuala oleh Ahmad Anshari. ${ }^{8}$ K.H. Ahmad Anshari juga berbaiat dengan K.H. Suni. Hal itu dilakukan, sematamata untuk mengambil hikmah dari senioritas agar kemuktabarahan dan keabsahan ilmu mereka lebih baik. Di samping menggambarkan solidaritas dan rasa kebersamaan di antara mereka, sehingga sesama pengikut tidak ada perbedaan dan perlakuan khusus. Hal tersebut senada dengan pepatah yang mengatakan, berdiri sama tinggi berduduk sama rendah.

K.H. Ahmad Anshari dipilih menjadi muqaddam tertinggi di Kalimantan Selatan. Ia dijadikan payung, pembina, dan pembimbing di daerah ini karena ia masuk tarikat Tijaniyah lebih dahulu daripada yang lain dan ilmu tarikat Tijaniyahnya cukup mendalam dan luas.

${ }^{6}$ K.H. Suni salah seorang ulama dan tokoh masyarakat yang cukup kharismatik, ia membuka pengajian tarikat Tijaniyah di rumah sendiri, Pendidikannya tidak melalui jenjang pendidikan formal, tetapi melalui Pondok Pesantren. (Hasil wawancara dengan K.H. Suni dan Fakrurrazi di Negara).

${ }^{7}$ K. Ahmad Nawawi (diberi gelar Ahmad Hiking) adalah salah seorang murid dari K.H. Suni Negara, dan K.H. Ahmad Anshari. Ia pimpinan Pondok Pesanten (Pondok ini tidak memiliki nama) di Kota Barabai, dan memimpin zawiyat tarikat Tijaniyah. Santri-santrinya yang berperan aktif dalam menyebarkan tarikat ini baik di Kota Barabai dan sekitarnya maupun di Pulau Bangka (Sumatera Selatan). Ia mengakui bahwa sebagian lulusan Pondok Pesantren ia kurang pandai atau pintar memimpin masyarakat, misalnya dalam memberikan ceramah kurang professional karena tidak bisa mengemas materi ceramah, sehingga masyarakat merasa bosan untuk menerimanya. Santri K. Ahmad Nawawi berjumlah 25 orang, 15 orang berasal dari Sumatera Selatan (Pulau Bangka). Mereka ini menginap di Pondok Pesantren dan 10 orang berasal dari masyarakat sekitarnya. Mereka tidak menginap. Santri tidak dipungut bayaran, kecuali dengan suka rela. (Hasil wawancara dengan K. Ahmad Nawawi dan Said di Barabai).

${ }^{8}$ Hasil wawancara dengan Ibrahim di Anjir Kota. 
Memperhatikan silsilah tarikat Tijaniyah di Kalimantan Selatan terdapat dua orang muqaddam yang langsung dibaiat oleh Syekh Idris al-Iraqi dan sama sanad atau silsilah yang diterima K.H. Suni dan K.H. Ahmad Anshari, akan tetapi K.H. Ahmad Anshari sebelumnya sudah berbaiat dengan K.H. Badri Masduqi.

Kalau diteliti dari silsilah dan sanadnya tersebut diatas, tarikat Tijaniyah yang dibawa K.H. Ahmad Anshari, adalah serumpun dan saling bertalian dengan tarikat Tijaniyah yang ada di Pulau Jawa, karena pada awalnya ia menerima pelajaran dan amalan-amalan dari K.H. Badri Masduqi, sedangkan syekh yang lainnya sebagai pengokohan keabsahan amalan tarikatnya.

\section{Perkembangan Tarikat Tijaniyah di Kalimantan Selatan}

Tarikat Tijaniyah mulai berkembang di Kalimantan Selatan pada tahun 1995 dibawa muqaddami K.H. Ahmad Anshari yang dipusatkan di Kota Banjarmasin. Ada dua sebab yang melatarbelakanginya dan mengajarkan tarikat ini kepada masyarakat. Pertama, ia mendapat isyarat untuk berpindah ke tarikat Tijaniyah oleh K.H. Badri Masduqi ketika ia menerima pelajaran dan amalanamalan kemudian disempurnakan oleh guru Syekh Ideris al-Iraqi. Kedua, ketika berziarah ke Mesir dan Maroko pada tahun 1991, ia dapati pengikut tarikat Tijaniyah sangat banyak di daerah ini dan Allah memberikan kesejahteraan, ketenteraman serta kedamaian bagi keluarga pengikut bahkan kepada kota di mana tarikat tersebut diamalkan.

Dengan kedua latar belakang tersebut di atas, timbullah dalam hati K.H. Ahmad Anshari untuk mengamalkan dan mengajarkan tarikat Tijaniyah. Ia menjadi muqaddam tunggal wilayah Kalimantan Selatan, Kalimantan Tengah dan Sumatera Selatan untuk menyebarluaskan ajaran Tarikat Tijaniyah, di samping ia terlebih dahulu mengembangkan tarikat ini di Mekkah selama tiga tahun.

Pada tahun 1992 K.H. Ahmad Anshari mendapat izin mengembangkan tarikat Tijaniyah di Mekkah dengan syarat tidak menampakkan aktivitasnya secara terang-terangan, kecuali Allah sendiri yang menampakkannya. Dengan kehendak Allah akhirnya tarikat Tijaniyah dikenal oleh orang-orang Banjar yang ada di Mekkah dan Madinah ketika musim haji. Di Mekkah ia mendirikan majelis taklim untuk orang Banjar khususnya, dan masyarakat Muslim Indonesia pada umumnya. Majelis Taklim ini dibuka karena ia melihat orang Indonesia banyak yang tidak pandai bahasa Arab, sementara kitab-kitab yang dipakai di dalam majelis-majelis taklim di Mekkah berbahasa Arab. 
Setelah tiga tahun mengembangkan tarikat Tijaniyah di Mekkah, pada tahun 1995, K.H. Ahmad Anshari dapat perintah dari guru Syekh Idris al-Iraqi agar ia pulang dan mengembangkan di Indonesia terutama di daerah Kalimantan Selatan.

K.H. Ahmad Anshari termotivasi sekali pulang kampung (Banjarmasin) dan menyebarkan tarikat Tijaniyah di daerah ini. Menurutnya, kondisi umat Islam di daerah ini pada saat itu sudah sangat parah dan rusak, terutama mental/moral dan ibadat. Misalnya setiap orang mengaku beriman kepada Allah swt, namun tidak dibarengi dengan amal saleh yang mendukung pengakuan tersebut. ${ }^{9}$

Pada tahun 1995, K.H. Ahmad Anshari mengembangkan tarikat Tijaniyah di Banjarmasin. Pengikutnya terbatas dari lingkungan keluarga. Pengajian secara berjamaah dilakukan satu kali seminggu di rumahnya sendiri. Beberapa tahun kemudian, pengikutnya bertambah banyak dan menyebar ke pelosok-pelosok kota Banjarmasin, bahkan ke kabupaten-kabupaten di Kalimantan Selatan, Kalimantan Tengah dan Sumatera Selatan terutama di Pulau Bangka. ${ }^{10}$

Setelah lima tahun K.H. Ahmad Anshari melaksanakan pengajian tarikat Tijaniyah yang bertempat di rumahnya, tempat pengaiian tersebut tidak dapat menampung pengikutnya. Atas prakarsa guru serta dukungan pengikutnya dibangun tempat pengajian (zawiyah) yang dapat menampung pengikut dalam jumlah banyak. Bangunan tersebut terdiri atas tiga tingkat atau lantai. Yang sudah selesai dua tingkat. Bangunan tersebut sudah tiga tahun digunakan sebagai tempat pengaiian, tahlilan, tahfiz dan tadarus Alquran serta kegiatan keagamaan lainnya. Tempat (zawiyah) ini bukan saja dikhususkan untuk pengikut tarikat, tetapi dipergunakan juga untuk umum, dengan tujuan untuk

${ }^{9}$ Hasil wawancara dengan K.H. Ahmad Anshari di Banjarmasin.

${ }^{10}$ Perkembangan tarikat Tijaniyah ini di Pulau Bangka Sumatera Selatan berawal dari banyak orang Pulau Bangka yang masuk pesantren di Barabai Kabupaten Hulu Sungai Tengah dan Martapura kabupaten Banjar, dimulai pada tahun 1908 orang Pulau Bangka datang ke Tahfiz untuk belajar mengaji, siapa orangnya tidak dijelaskan. Kemudian datang lagi yang bernama Makruf untuk belajar ke Martapura, sebelumnya belajar di Barabai dan ia kembali lagi ke Barabai. Mereka ini yang memberikan informasi ke Pulau Bangka, akhirnya banyak orangorang Pulau Bangka masuk pendidikan di dua daerah tersebut. Tapi yang paling banyak di Barabai, termasuk di Pesantren K. Ahmad Nawawi. Pada sisi lain, seorang Banjar yang bernama Abdurrahman Siddiq telah menikahi (tapabini) di Pulau Bangka. Inilah keterkaitan orang Banjar dengan orang Pulau Bangka Sumatera Selatan yang sampai sekarang terus berlanjut. (Hasil wawancara dengan K. Ahmad Nawawi di Barabai). 
lebih meningkatkan nilai-nilai keagamaan bagi umat Islam di daerah ini. Zawiyah ini diberi nama Al-Furqan.

Walaupun tarikat Tijaniyah relatif masih muda usianya di Kalimantan Selatan, tarikat ini sudah maju pesat dalam perkembangannya, jika dibandingkan dengan tarikat lainnya, seperti tarikat Qadiriyah Naqsyabandiyah, Awaliyah, Syazaliyah, Sammaniyah, Junaidiyah, Awaliyah dan Sanusiyah. Hal ini dapat dilihat dari jumlah pengikut yang berhasil diserap berjumlah kurang lebih 15.000 orang serta memiliki 21 majelis taklim yang membantu menyebarkan ajarannya. Semua itu dipusatkan di Kota Banjarmasin beralamat di Jalan Cempaka Sari Raya RT. 74 No. 19 Kelurahan Telaga Biru dipimpin langsung oleh K.H. Ahmad Anshari. Majelis Taklim di Kabupaten Hulu Sungai Utara tepatnya di desa Bitin dan Sungai Haji Kecamatan Danau Panggang desa Sungai Luang Kecamatan Babirik dipimpin oleh Aspawi. ${ }^{11}$ Dan di kabupaten Hulu Sungai Tengah berpusat di kota Barabai beralamat di Jalan Sarigading desa Banua Binjai Rt. 02 membawahi sebanyak lima desa, yaitu desa Rasau, Mandiangin, Hukung, Kapas dan Kapar, dipimpin Kiai Ahmad Nawawi bin Salam. Majelis taklim di Kabupaten Hulu Sungai Selatan dipusatkan di daerah Pasongkan dan tambangan Bitin Negara di rumah guru K.H. Suni, Kabupaten Banjar di desa Pengaron Jalan Mandarijo Sungai Pinang dipimpin oleh H. Abdul Samad dan Masjid Pancasila Simpang Tiga Sekumpul Martapura dipimpin oleh H. Ahmad. Kabupaten Batola yaitu Anjir Kota Km. 18 RT. 1 No. 13 dipimpin oleh Ibrahim, Kabupaten Tabalong di desa Sulingan, dan Tamban Km 12 Desa Tamban Raya Kecamatan Mekar Sari. Para pengikut tarikat ini juga tersebar di Kabupaten Tanah Laut, Kabupaten Kotabaru dan Kabupaten Tapin. Kemudian tarikat ini berkembang ke Kalimantan Tengah di Sampit dan Palingkau, serta Pulau Bangka Sumatera Selatan. Bahkan menurut K.H. Ahmad Anshari akan dikembangkan di Medan dan Aceh. Dari 21 majelis taklim tersebut, yang mempunyai tempat atau zawiyah sendiri adalah kota Banjarmasin, Desa Bitin Kabupaten Hulu Sungai Utara, Anjir Kabupaten Batola, dan Barabai Kabupaten Hulu Sungai Tengah. Selebihnya menggunakan rumah guru yang mengajar atau pada tempat ibadat seperti mushalla atau masjid dan bisa juga secara bergiliran dari rumah ke rumah pengikutnya.

${ }^{11}$ Kiai Aspawi salah seorang guru/badal untuk kecamatan Babirik Kabupaten Hulu Sungai Utara, berhubung guru/badal di desa Bitin kecamatan Danau Panggang meninggal dunia, untuk mengisi kekosongan di desa Bitin, Kiai Aspawi juga mengisi pengajian di desa tersebut sehingga, ia bolak balik antara kecamatan Babirik dan desa Bitin kecamatan Danau Panggang. (Hasil wawancara dengan K. Ahmad Nawawi dan Said di Barabai). 
Pada muqaddam dan badal tarikat Tijaniyah di daerah ini memberikan kebebasan kepada calon pengikut untuk terlebih dahulu mempelajari mendalam dan mengamalkan wirid dan istigfae maupun shalawat, terkecuali salawat Jauharatul Kamal, menurut mereka, salawat Jauharatul Kamal tidak bisa diamalkan oleh sembarangan orang. Kalau seseorang berkeinginan untuk mengamalkan shalawat itu, harus bersuci, suci badan, pakaian, tempat,d an harus duduk. ${ }^{12}$

Setelah berpikir panjang dan hati yang mantap, calon pengikut tarikat boleh menyatakan masuk (dibaiat) ${ }^{13}$ atau bisa mengurungkan niatnya untuk tidak menjadi pengikut tarikat. Sebab, untuk syarat masuk tarikat Tijaniyah minimal harus memenuhi tiga persyaratan. Pertama, calon pengikut Tijaniyah tidak mempunyai wirid tarikat lain, karena menurut mereka, jika ia mempunyai wirid lain dikhawatirkan dalam pengamalannya hati menjadi mendua atau bercabang, jika ini terjadi biasanya sering kali menemui kegagalan atau amalan tidak mencapai tujuan yang dikehendaki, apalagi menurut mereka, Allah tidak menyukai hati manusia yang mendua atau bercabang. Kedua, orang yang mentalkinkannya telah mendapat izin yang sah untuk memberikan wirid tarikat Tijaniyah. Ketiga, mencapat izin mengamalkan wirid tarikat tersebut. ${ }^{14}$

Selain tiga persyaratan di atas calon juga harus sanggup menerima segala ajaran atau wirid yang diberikan oleh muqaddam tarikat ini, karena calon bisa saja ingkar janji. Hal inilah yang sering mereka persoalkan dan ragukan. Baiat itu sesungguhnya adalah janji seseorang kepada Allah untuk mentaati segala aturan dan menjauhi segala larangan-larangan-Nya. Agar janji tersebut betulbetul mendalam maka perlu disaksikan seorang yang alim, yaitu guru (mursyid). Jadi, baiat sebenarnya bukanlah janji seseorang kepada guru, tetapi janji kepada Allah. Fungsi guru dalam berbaiat tersebut hanyalah sebagai saksi. Kalau ada saksinya janji itu akan selalu diingat oleh yang melakukannya. Oleh karena itu, menjadi pengikut tarikat itu sangat berat dan besar godaannya.

Tarikat Tijaniyah di Kalimantan Selatan tidak bersifat eksklusif, maksudnya bukan hanya berlaku bagi kalangan sendiri, akan tetapi berlaku h. 69 .

${ }^{12}$ A. Syinqithy Djamaluddin, Kunci Rahmat Ilabi, (Jawa Timur: Pustaka at-Tijani, 2000),

${ }^{13}$ Proses bertalkin ini dengan cara antara guru (mursyid) dengan calon pengikut tarikat berjabatan tangan dalam posisi duduk sebagaimana duduk tahyat awal dalam salat. Setelah itu, guru (mursyid) mentalkinkan calon pengikut tarikat dengan lafaz; Aku izinkan kamu mengamalkan wirid tarikat Tijaniyah sepanjang hidupmu sampai meninggal dunia. (Hasil wawancara dengan Muhammad Nor dan Muhdi di Banjarmasin.

${ }^{14}$ Fauzan Fathullah, Tafi al-Quthbul Maktum Sayidul Awliyaa Syekh Abmad at-Tijani dan Tarekatnya at-Tijani, (Banjarmasin: Ikatan Pengamal Kalimantan, t.th), h. 118. 
untuk umum, terutama dalam pengajian, sehingga orang lain juga merasa dihargai dan akan sadar bahwa Islam adalah untuk sesama makhluk.

Dilihat banyaknya jumlah pengikut tarikat Tijaniyah di Kalimantan Selatan sejak mulai berdirinya sampai sekarang, tarikat ini dapat dikatakan mengalami kemajuan dari segi kuantitas. Selain itu jumlah pengikut yang banyak, menggambarkan betapa besar perhatian masyarakat Banjar terhadap ilmu-ilmu keagaman terutama ilmu-ilmu kerohanian atau olah batin. Hal ini didukung oleh penduduk Kalimantan Selatan yang mayoritas beragama Islam dan penganut paham Ahl al-Sunnah wal Jamaah atau beraliran Sunni, di samping masyarakat Banjar yang suka menghormati kiai atau ulama dan selalu memegang apa yang difatwakan kiai atau ulama tersebut. Hal ini memudahkan tarikat Tijaniyah dalam beradaptasi dan menjalankan aktivitasnya, sehingga mengalami perkembangan yang cukup pesat.

Begitu pula, K.H. Ahmad Anshari berkeyakinan bahwa tarikat Tijaniyah akan berkembang sesuai dengan yang dikehendaki Allah. Tidak perlu popularitasnya di ekspose melalui surat kabar karena akan timbul dengan sendirinya. Ia menambahkan semakin tarikat ini ditantang atau dimusuhi, maka semakin bertambah pengikutnya. Hal ini bukti bahwa tarikat ini sampai sekarang terus bertambah pengikutnya dan tetap eksis di kalangan masyarakat Islam.

Pengikut tarikat Tijaniyah di Kalimantan Selatan berasal dari berbagai strata sosial masyarakat, seperti penguasa, pegawai negeri, tokoh-tokoh agama, pedagang dan petani, yang tersebar di seluruh pelosok daerah. Dilihat dari karakteristik pengikut tarikat ini, yang terbanyak adalah dari golongan petani. Tersebarnya pengikut tarikat Tijaniyah dalam berbagai strata sosial, tentunya ikut mendorong kemajuan dan perkembangannya, karena hampir di setiap kabupaten di Propinsi Kalimantan Selatan ada pengikut tarikat tersebut. Keberadaan mereka ini agak sulit dikenali sebab, menurut pengamatan penulis, mereka tidak memiliki karakteristik tersendiri dalam kehidupan masyarakat, kecuali ketika diadakan pengajian biasanya mereka memakai pakaian yang serba putih. Mengapa mereka memakai pakaian serba putih? Menurut mereka pakaian serba putih melambangkan kesucian, naik kesucian lahir maupun kesucian batin.

Berbagai kegiatan yang dilakukan pengikut Tijaniyah di atas menunjukkan ciri keaktifannya sebagai tarikat neosufi. Tarikat Tijaniyah tidak mengajarkan kepasifan, kejumudan dan keterbelakangan tetapi sangat mementingkan kemajuan. Salah satu upaya yang dilakukan ialah kesepakatan 
pembentukan organisasi yang dapat mengurus administrasi tarikat sehingga seluruh kegiatan dapat berjalan dengan baik dan lancar. Secara teologis, Tijaniyah berpijak teguh pada sumber ajaran Islam. Oleh karena itu, menurut pengikut Tijaniyah ajaran tarikat ini tidak bertentangan dengan syariat. Walaupun ada serangan terhadap ajaran-ajaran Tijaniyah tampaknya berawal dari kesalahpahaman dan kekhilafan karena dalam sufisme terdapat banyak ajaran dan ungkapan simbolis yang membutuhkan pentakwilan. Oleh karena itu, menurut K.H. Badri Masduqi, pertentangan itu bersifat khilafiyah dan bukan masalah akidah. Khilaf atau perselisihan di bidang akidah harus dibendung. Hanya akidah Ahlussunnah yang harus tegak berdiri. ${ }^{15}$

\section{Wirid-Wirid Tarikat Tijaniyah}

Berdasarkan hasil wawancara, wirid tarikat Tijaniyah pada dasarnya sangat sederhana, simpel, dan mudah diamalkan oleh setiap orang. ${ }^{16}$ Wirid tersebut dibagi tiga, yaitu wirid Lazim, wirid Warifah dan wirid Haylalah. Susunan wirid tarikat ini diuraikan satu per satu sebagai berikut:

\section{Wirid Lazim}

Wirid Laz̧m diamalkan sehari semalam dua kali, yaitu pagi hari, waktunya setelah shalat subuh sampai waktu Dhuha. Apabila ada uzur, waktunya bisa diperpanjang sampai waktu Maghrib. Kedua, sore hari, waktunya setelah shalat Ashar sampai shalat Isya. Orang yang mengamalkan wirid lazim ini akan memperoleh keutamaan, pahala yang besar, dan tidak akan masuk neraka; juga turut bersamanya kedua orang tua, istri-istri, dan anak-anaknya. Jika waktu wirid sudah habis, tapi belum dikerjakan, harus diqada. ${ }^{17}$

Wirid Lazim yang harus dibaca setiap pagi dan sore tersebut adalah sebagai berikut:

a. Membaca istighfar $100 \mathrm{kali}$, (Astagfirullabal Ažm al-laz̧i la ilaba illa buwal bayyul qayyum)

\footnotetext{
15Zulkifli, Neo Sufisme di Indonesia Pemikiran dan Perkembangannya. (Palembang: Puslit IAIN Raden Fatah, 1997), h. 86.

${ }^{16}$ Hasil wawancara dengan Ibrahim di Anjir Kota.

${ }^{17}$ Hasil wawancara dengan H. Ahmad Anshari, H. Samani dan Anshari Arsyad di Banjarmasin. Lihat juga Sayid Abdullah Dahlan, Tanbihul Ghafil wa Irsyadul Mustafidi’i Aqil, Terj. Bahrun Abu Bakar, Tarekat Tijaniyah suatu Pertanyaan. (Jakarta: Andamera Pustaka. 1987), h. 31., dan Fauzan Fatullah, op. cit., h. 137. Lihat juga Bearman PJ., dkk, (et-al). The Encyclopedia of Islam. (Leiden: Bruth, 2000), h. 465.
} 
b. Salawat kepada Rasulullah saw sebanyak 100 kali. Lafal shalawat boleh apa saja sekalipun dengan singkat, namun yang diutamakan adalah salawat fatib.

c. Membaca Haylalah sebanyak 100 kali, (Lailaha illallab).

Pada bacaan keseratus ditambah dengan :

(Mubammadur Rasulullabi alaibi Salaamu Ilahi). ${ }^{18}$ Namun sebelum membaca wirid lazim itu, terlebih dahulu harus didahului mukaddimah dengan membaca surat al-Fatihah dan shalawat Fatih tiga kali.

2. Wirid Warifah

Wirid Warifah dibaca dua kali, siang dan malam. Kalau wirid tersebut tidak dikerjakan pada waktu siang, maka bisa dikerjakan pada malam hari, lebih diutamakan. Apabila sehari semalam tidak dikerjakan sama sekali, harus diqada. ${ }^{19}$ Wiridnya adalah sebagai berikut:

a. Membaca istighfar warifah sebanyak $30 \mathrm{kali}$, bacaannya (Astagfirullabal Azim al-lazi la ilaha illa buwal hayyul qayyum)

b. Membaca salawat Fatib sebanyak 50 kali.

c. Membaca Haylalah sebanyak 100 kali. (Lailabaillah)

d. Membaca Jauharatul Kamal satu kali.

e. Ditutup dengan wirid.

Sebelum menggunakan wirid Warifah pengikut tarikat ini terlebih dahulu membaca mukaddimah sebagaimana mukaddimah wirid Lazim.

3. Wirid Haylalab

Waktu wirid Haylalab adalah setelah shalat Ashar pada hari Jumat sampai waktu Maghrib. Apabila seseorang ada uzur dan tidak mengamalkannya sampai waktunya habis, tidak perlu diqada.

Wirid haylalah juga didahului dengan membaca surat al-Fatihah, salawat Fatih sebanyak tiga kali, dan wirid haylalah atau membaca Allah tanpa hitungan sampai Maghrib. Kalau sendirian dibaca sebanyak 1600 atau 1500 atau 1200 atau 1000 kali, dan diakhiri dengan: Lailahaillah saidina Muhammadur Rasulullah saw).

\footnotetext{
${ }^{18}$ Hasil wawancara dengan H. Ahmad Anshari, Bhina Heriwidodo dan Muhdi di Banjarmasin dan Muhammad bin Abdullah bin Husaini asy-Syafi'i at-Tasfawi At-Tijani, op. cit., h. 9 .

${ }^{19}$ Hasil wawancara dengan H. Ahmad Anshari, Anshari Arsyad dan Muhdi di Banjarmasin dan Muhammad bin Abdullah bin Husaini asy-Syafi'i at-Tasfawi At-Tijani, ibid., h. 51-52 dan 83-84, serta, Muhammad al-Arabi an-Saih asy Syurqi Umar At-Tijani. Bughyatul Mustafid Lisyarthi Munyatil Murid. (Dar al Fikr: 1973 M/1393 H), h. 349-350 dan 361.
} 
Secara garis besar, ajaran tarikat Tijaniyah meliputi amalan istighfar, shalawat, dan rikir. Selain tiga wirid tersebut ada juga ajaran mengenai ilmu, harta, kerja dan moral yang disisipkan pada setiap pengajian, karena dalam pengajian tidak saja membaca dan mengamalkan istighfar, shalawat dan rikir, juga diisi dengan ceramah agama. Ajaran-ajaran demikian hanya diperoleh melalui mata rantai hubungan guru-murid. Hal ini menunjukkan betapa ketat dan sistematisnya tarikat ini mempertahankan konsep rabitah, sehingga ajaranajarannya disampaikan melalui mata rantai guru-murid tersebut.

Dalam hal salawat, pengikut tarikat Tijaniyah memiliki jenis salawat yang berbeda-beda. Demikian pula panjang dan pendeknya tergantung pemberian (ijazah) guru-mursyid, yakni Syekh atau muaqaddam itu sendiri. Menurut pengikut tarikat ini, panjang pendek salawat yang diberikan guru menunjukkan tinggi rendahnya tingkatan seseorang dalam bertarikat. Salawat yang lebih diutamakan untuk diamalkan oleh pengikut Tijaniyah adalah salawat Fatih dan salawat Jaubaratul Kamal.

Kedua salawat itu merupakan salah satu ciri khusus yang membedakan tarikat ini dengan tarikat lainnya. Menurut mereka, salawat Jaubaratul Kamal tidak bisa diamalkan oleh sembarang orang karena kalau seseorang berkeinginan mengamalkan salawat itu harus berzuci, suci badan, pakaian dan tempat, serta harus duduk menghadap kiblat. ${ }^{20}$ Bahkan, menurut pengakuan mereka, kalau seseorang berkeinginan membaca atau mengamalkan salawat itu tidak akan mau hafal dan tidak akan mendapat berkah kecuali berbaiat dengan guru atau mursyid terlebih dahulu.

Salawat adalah bentuk jamak dari shalat, yang berarti doa. Salawat Nabuwah dapat diartikan doa untuk Nabi saw. Walaupun salawat Nabi itu adalah doa untuk Nabi, oleh para pengikut tarikat Tijaniyah diyakini mempunyai khasiat yang bermacam-macam. Pengikut tarikat ini menjelaskan bahwa khasiat membaca salawat ialah menjadikan segala permintaan akan menjadi mudah dikabulkan Allah swt. Allah telah berjanji akan memasukkan ke dalam surga, serta terhindar dari jamahan api neraka bagi yang mengamalkannya. ${ }^{21}$

${ }^{20}$ Hasil wawancara dengan H. Ahmad Anshari, H. Samani, Teguh Sucipto dan Fahrurrazi di Banjarmasin dan A. Syinqithy Djamaluddin, op. cit., h. 69.

${ }^{21}$ Hasil wawancara dengan H. Ahmad Anshari, H. Samani, Rosadi dan Anshari Arsyad di Banjarmasin dan Muhammad ibn Umar an-Nawawi al-Bantani, Tanqibul Qaul al-Hatsists, (Bandung: Trigenda Karya, 1994), h. 65-75. 
Bacaan salawat Nabi jumlahnya cukup banyak. Masing-masing salawat itu memiliki khasiat tersendiri. Tetapi semuanya memiliki watak menyejukkan bagi yang membaca, bagai mendapat siraman air. Hal ini berbeda dengan zikir yang membuat badan terasa panas. Oleh karena itu sebelum membaca zikir seseorang terlebih dahulu harus membaca salawat dan apabila dalam zikir telah terasa panas ia harus kembali membaca salawat.

Pengikut tarikat Tijaniyah disuruh membaca salawat kepada Nabi saw., sebab Nabi Muhammad saw adalah makhluk yang paling tahu, yang paling makrifat dan yang terdekat dengan Allah swt. Karena itu, dalam menghadap dan menuju wusul kepada Allah swt., serta mendekatkan diri kepada Nabi dilakukan dengan cara memperbanyak membaca dan mengamalkan salawat.

Pembacaan haylalah (La ilaha illallab) dilakukan dengan suara keras atau nyaring jika dibaca berjamaah dan dengan suara yang cukup didengar sendiri kalau dibaca sendirian. Dalam tarikat Tijaniyah membaca dan mengamalkan baylalah mempunyai tingkatan, seperti bagi orang yang baru masuk (orang awam) tarikat ini kalimat haylalah itu hanya dimaknai tidak ada yang berhak disembah kecuali Allah, bagi orang yang sudah hampir matang dalam mengamalkan amalan tarikat ini (sebut saja golongan orang khawas) baylalab dimaknai tidak ada yang bergantung atau bermaksud kecuali Allah, dan bagi orang yang sudah matang dalam pengamalan amalan tarikat ini (sebut saja golongan khawasul khawas) kalimat haylalah dimaknai tidak ada yang dicintai kecuali cinta kepada Allah swt. ${ }^{22}$

Dalam tarikat Tijaniyah mengamalkan kalimat haylalah tidak sampai kepada hu. Menurut pengakuan mereka, kalimat La ilaba illallah semulia-mulia dan seafdal zikir. Kalimat zikir itu banyak ditampilkan dan disebutkan dalam Alquran. Misalnya La ilaha illallah buwal bayuya qayyum dan cara mengamalkannya sebagaimana kebanyakan orang bertahlil atau berzikir. ${ }^{23}$ Lain halnya dengan tarikat Qadiriyah, Junaidiyah, Suhrawardiyah, dan tarikat Syatariyah. Tarikat-tarikat ini dalam membaca dan mengamalkan kalimat La ilaba illallah sampai kepada $b u$, dengan cara mata dipejamkan, kemudian diarahkan tepat ke tengah-tengah dada menuju ke arah dalam rasa dan ada juga dipukulkan ke kiri dan ke kanan.

Zikir La ilaba illallah mempunyai pengaruh yang sangat besar pada saat kematian untuk menghapus dan mencuci kesalahan dan dosa-dosa, baik dosa

\footnotetext{
${ }^{22}$ Muhammad bin Abdullah bin Husaini asy-Syafi'i at-Tasfawi At-Tijani, op. cit., h. 77.

${ }^{23}$ Hasil wawancara dengan H. Ahmad Anshari, Muhdi dan Fahrurazi di Banjarmasin dan Muhammad al-Arabi an-Saih asy Syurqi Umar At-Tijani , op. cit., h. 393.
} 
kecil maupun dosa besar, baik dosa yang sedikit maupun dosa yang banyak karena kalimat itu merupakan saksi atas seorang hamba yang beriman, yang syahwatnya telah terkubur, hawa nafsunya terkebiri, hamba yang bertobat setelah melakukan kemaksiatan, kembali setelah berpaling merendahkan diri setelah masa kesombongan, dan lain-lain. Pada pokoknya, zikir itu merupakan pernyataan penyesalan dan tersendu bersimpuh di hadapan-Nya. Ia diterima lahir dan batin, baik dalam keadaan sepi maupun ramai. Hatinya telah bersih dari segala ketergantungan dan berpaling kepada selain Allah. Kalimat zikir seperti ini yang akan menyucikan seseorang dari dosa-dosanya. ${ }^{24}$

Zikir haylalab itu diamalkan secara rutin pada hari Jumat sore hingga malam harinya secara serentak dilaksanakan di Kalimantan Selatan, dimulai dari pukul 17.00 wita sampai selesai, diisi dengan mukaddimah yang terdiri dari pembacaan surat al-Fatihah dan salawat Fatih tiga kali. Setelah itu berniat dan diteruskan dengan membaca warifah yaumiyah berisi istighfar 100 kali, salawat 100 kali, salawat Fatih 50 kali dan dilanjutkan membaca La ilaha illallah atau membaca Allah tanpa hitungan sampai menjelang shalat Maghrib. Selesai shalat Maghrib dilaksanakan pengajian hukum Islam (bertahkim) dan ditutup dengan bacaan al-Fatihah dan doa sampai menjelang waktu shalat Isya. Setelah shalat Isya, dilaksanakan acara khusus untuk pengikut tarikat Tijaniyah sampai sekitar pukul 21.00 malam, yang diisi amalan-amalan yang telah ditentukan mursyid (guru).

Wirid tarikat Tijaniyah yang diberikan kepada Ahmad at-Tijani oleh Rasulullah saw., yang terdiri dari tiga unsur itu harus dibaca tertib dan tartil, yaitu istighfar, salawat (salawat fatih dan salawat Jauharatul Kamal) dan haylalah (La ilaha illallah). Istighfar, salawat dan zikir sudah diajarkan oleh Rasulullah saw baik melalui Alquran maupun sunah agar bisa dilaksanakan oleh seluruh umat Islam dalam mendekatkan diri kepada Allah dan merupakan bagian dari ajaran agama yang urgan, karena ia merupakan tiang yang kuat untuk menuju Allah swt. Seseorang tidak dapat mencapainya kecuali dengan terus menerus mengamalkan wirid tersebut. Agar wirid (istighfar, salawat, zikir) itu diterima Allah swt seseorang harus memenuhi persyaratan. Persyaratan melakukan wirid diantaranya suci dari hadas dan najis, menutup aurat, menghadap kiblat, duduk,

${ }^{24} \mathrm{Ibnu}$ Qayyim al-Jauziyah, Al-Fawaid, Terj. Munirul Abidin, Al-Fawaid Menuju Pribadi Takwa, (Jakarta: Pustaka al-Kausar, 2000), h. 58-59. 
dilakukan dengan sepenuh hati, rasa takut kepada Allah, merendahkan diri dan dengan suara perlahan cukup didengar sendiri. ${ }^{25}$

Ketiga wirid tersebut mendekatkan diri seseorang kepada Allah swt karena ia selalu sibuk baik siang maupun malam dengan wirid. Hatinya tidak pernah terlepas dari mengingat Allah, maka ia mencapai kesempurnaan (makrifat) kepada Allah. Dengan demikian, kehidupan seseorang menjadi tenang, tenteram, bahagia dan selamat dunia maupun akhirat, bahkan balasannya surga.

Menurut pengikut tarikat Tijaniyah, apabila seseorang masuk tarikat Tijaniyah dan mengamalkan ketiga wirid (istighfar, salawat, zikir) tersebut, ia akan ditanggung oleh Ahmad at-Tijani masuk surga tanpa hisab dan siksaan. ${ }^{26}$ Menurut penulis, tanpa masuk tarikat Tijaniyah maupun tarikat yang lainnya, asalkan seseorang mengamalkan secara terus menerus sepanjang hidupnya ketiga wirid di atas, Allah menjamin orang itu masuk surga dan akan terhindar dari jamahan api neraka. Hal ini sejalan dengan firman Allah swt dan hadis Rasulullah saw.

Mengenai pernyataan Ahmad at-Tijani bahwa seseorang yang masuk tarikat Tijaniyah akan ditanggung masuk surga tanpa hisab, merupakan suatu jaminan kepada setiap orang yang masuk tarikat ini. Apabila ditelusuri hadis Rasulullah saw ditemukan bahwa tidak ada jaminan masuk surga, terkecuali sepuluh orang yang dijamin oleh Allah masuk surga, sebagaimana sabda Rasulullah saw: yang artinya "Dari Abdurrahman ibn Auf berkata: bersabda Rasulullah saw: Abu Bakar, Umar, Usman, Ali, Thalhah, Jubair, Abdurrahman bin Auf, Abi Wakas, Jaid dan Abu Ubaidah bin Jurahi. Mereka semua masuk surga"

Rasulullah saw bersabda, yang artinya: "Diperlihatkan kepada saya berbagai umat yang berkumpul. Kemudian saya melihat umatku memenuhi lembah dan gunung. Mereka jumlahnya banyak dan kehebatannya mengagumkan saya. Setelah itu saya ditanya: Apakah engkau rela? Saya menjawab, "Ya". Bersama mereka terdapat 70.000 orang yang masuk surga

${ }^{25}$ Hamzah Yaqub, Tingkat Ketenangan dan Kebahagiaan Muslim (Tasawnf dan Takarrub), (Jakarta: Atisa, 1992), h. 312.

${ }^{26}$ Hasil wawancara dengan Ahmad Nawawi dan Said di Banjarmasin dan Fauzan Fatullah, op. cit., h. 95. 
tanpa dihisab, karean mereka itu tidak menipu, tidak menghambur-hamburkan harta, dan tidak mencuri, kepada Tuhannya mereka menyerahkan diri"' ${ }^{27}$

Menurut kedua hadis Rasulullah saw tersebut hanya mereka itu yang dijamin masuk surga tanpa dihisab; selebihnya, manusia akan diproses perhitungan amal saleh yang diperolehnya selama hidup di alam dunia. Apabila amal salehnya banyak, ia akan dimasukkan ke surga, apabila dosanya lebih banyak, ia akan dimasukkan ke dalam neraka. Dalam hal ini Allah swt berfirman yang artinya: "Pada hari itu manusia keluar dari kuburnya dalam keadaan yang bermacam-macam, supaya diperlihatkan kepada mereka (balasan) pekerjaan mereka. Barangsiapa yang mengerjakan kebaikan sebarat zarrah pun, niscaya dia akan melihat (balasan)nya. Dan barangsiapa yang mengerjakan kejahatan seberat zarah pun, niscaya ia akan melihat (balasan)nya pula. (Q.S. al-Zalzalah: 6-8).

Pernyataan Ahmad at-Tijani itu cukup kontroversial, karena ia telah berani menjamin orang masuk surga dan tanpa hisab terutama mereka yang masuk tarikat Tijaniyah. Hal ini yang sering diperdebatkan orang mengenai kehadiran tarikat ini

Untuk lebih mantapnya pengamalan ketiga macam wirid di atas, seorang pengikut tarikat Tijaniyah harus melaksanakan perintah dan aturan yang harus dipenuhi, yaitu :

1. Peraturan melaksanakan zikir

a. Dalam keadaan normal bacaan zikir harus terdengar oleh telinga si pembaca,

b. Harus suci dari najis, baik badan, pakaian, tempat maupun apa saja yang dibawahnya,

c. Harus suci dari hadas, baik hadas besar maupun hadas kecil,

d. Harus menghadap kiblat dan duduk,

e. Harus menutupi aurat sebagaimana dalam shalat baik bagi pria maupun wanita,

f. Tidak boleh berbicara,

g. Harus ijtimak dalam melasanakan wazifah dan haylalah sesudah Asar hari Jumat apabila di daerahnya ada pengikut.

h. Istihdarul qudwah, yaitu melaksanakan wirid dari awal sampai akhir membayangkan seakan-akan berada di hadapan Ahmad at-Tijani dan

${ }^{27}$ Hadis riwayat Ibnu Masud yang dikutif Abu Qasim Abdul Karim Hawazin alQusyairi An-Naisaburi, Risalah Qusyairiyah fil Ilmu at-Tasawnf, (Beirut : Dar al Fikr, t.th), h. 162. 
yang lebih utama membayangkan berada di hadapan Saiyidul Wujud saw dengan keyakinan bahwa beliau pembawa dan wusul Ilallah,

i. Mengingat dan membayangkan makna wirid dari awal sampai akhir, Kalau tidka bisa, supaya memperhatikan dan mendengarkan bacaan wiridnya. ${ }^{28}$

2. Tata Tertib sebelum Berzikir

a. Bertobat, yaitu meninggalkan perkataan dan perbuatan serta kehendak yang tidak penting buat dirinya,

b. Suci dari hadas dan kotoran dengan sempurna,

c. Diam dan tenang,

d. Mohon bimbingan kepada Allah swt melalui Syekh dengan sepenuh hati ketika hendak memulai zikir sampai selesai, seolah-olah dirinya ditemani Syekh di dalam menghadap Allah,

e. Tahu kalau bimbingan Syekh adalah bimbingan Rasulullah saw karena bimbingan Syekh juga bimbingan Rasulullah saw.

3. Tata Tertib pada waktu berzikir

a. Duduk bersila di atas tempat yang suci seperti hendak mengerjakan salat, lebih sopan lagi kalau duduk seperti dalam shalat. Apabila munfarid harus menghadap kiblat, tapi kalau berjamaah harus membentuk tahlil,

b. Meletakkan kedua tangan di atas kedua paha,

c. Memakai wewangian, baik di tempat berzikir atau badan dan mulut. Dianjurkan agar bau-bau yang tidak sedap dijauhkan dari majelis zikir sebab malaikat dan jin mukmin tidak menerimanya. Kalau para malaikat menjauhkan diri dari majelis zikir, bimbingan dapat terputus.

d. Memakai pakaian bagus, halal dan wangi,

e. Tempat zikir sebaiknya gelap, kalau ada lampu sebaiknya dipadamkan,

f. Memejamkan kedua mata agar hati lebih konsentrasi, karena indra lahir terputus dari dirinya,

g. Mendatangkan bentuk guru di hadapannya, sesuai dengan kemampuan,

h. Jujur, yaitu keselarasan batin dan lahirnya,

i. Ikhlas. Maksudnya amal perbuatan dilakukan dengan bersih tanpa mengharapkan keuntungan dunia, tidak pula di akhirat, pahala dan kenaikan pangkat melainkan dia semata zikir karena cinta kepada Allah,

${ }^{28}$ Hasil wawancara dengan H. Ahmad Anshari, Ahmad Nawawi dan Said di Banjarmasin dan Barabai, Lihat juga Fauzan Fatullah, op. cit., h. 112. 
j. Berzikir dengan penuh semangat, menggoyangkan kepala ke arah kanan pada ucapan "La" dikembalikan ke arah dada pada ucapan "ilaha" dan pada ucapan "illallah" ditekan ke hati, yaitu di bawah susu sebelah kiri, alasan hakikat membakar hangus segala kejelekan yang bersarang di dalam hati,

k. Menghayati kandungan setiap zikir yang diucapkan sampai seoleh-olah hatinya berzikir, sementara dia mendengarkannya,

1. Memusnahkan segala yang ada di dalam hati selain Allah dengan kalimat tauhid La ilaha illallah.

4. Tata Tertib Sesudah Berzikir

a. Setelah berzikir dianjurkan agar diam dan tenang menghayati seluruh zikir yang telah diucapkan, memperhatikan kalau ada warid yang datang kepadanya. Boleh ada sesuatu warid yang datang dalam sekejap, tapi nilainya melebihi warid yang dicari selama tiga puluh tahun lebih. Agar warid tidak menghilang begitu saja dianjutkan agar diam dan tenang serta penuh penghayatan,

b. Bermurakabah kepada Allah seolah-olah Allah dihadapannya,

c. Harus penuh konsentrasi baik dalam menerima warid maupun dalam mengamalkannya,

d. Harus selalu mengendalikan diri sampai wirid yang datang bersirkulasi pada seluruh faktornya. Warid sangat efektif membuat hati bersih, menyingkap hijab, dan mematahkan bisikan-bisikan nafsu dan syaitan,

e. Jangan minum setelah berzikir atau waktu tengah berzikir. Zikir punya kalori yang dapat menimbulkan cahaya, membuat segalanya terang. Tajjali mendatangkan dan membangkitkan kerinduan terhadap Allah. Sedangkan air dapat menghilangkan kalori zikir. Sebab itu, bersabar agar jangan terburu-buru minum, satu setengah jam setelah berzikir. Lebih lama lebih baik. Bahkan kelompok utama hampir tidak mau minum kecuali sangat terpaksa. ${ }^{29}$

5. Syarat Sah Mengamalkan Wirid

a. Wajib suci dari hadas, baik dengan air atau tayamum sebagaimana ditetapkan dalam syariat,

b. Wajib suci dari najis, baik pakaian, jasad ataupun tempat.

c. Wajib menutup aurat sebagaimana ditetapkan di dalam shalat,

d. Tidak boleh bicara, mulai awal sampai selesai, kecuali ada uzur. Apabila ada uzur, dima'fu dengan satu atau dua kata pada waktu pertengahan 
wirid, kecuali karena memenuhi panggilan ayah ibu, maka boleh memenuhinya sesuai dengan keperluan mereka berdua. Sebab, memenuhi panggilan mereka itu disenangi Allah yang Maha Pengasih. Demikian pula istri, dia boleh memenuhi panggilan suami sesuai dengan kehendak suami.

e. Niat membaca wirid. Pada waktu berniat wajib ditentukan waktunya apakah wirid sabah (pagi) atau wirid masa' (malam). ${ }^{30}$

Ajaran tarikat Tijaniyah memiliki ciri khusus yang membedakan dari tarikat lainnya. Tarikat ini membuat format baru karena Ahmad at-Tijani pendiri tarikat ini, tidak mengharuskan pengikutnya menunjukkan sikap ketakwaan yang berlebihan dan ritualnya yang rumit. Ahmad at-Tijani menekankan pentingnya keberadaan juru syafaat antara manusia dan Tuhan. Di zamannya, juru syafaat itu adalah Ahmad at-Tijani sendiri.

Pengakuan Ahmad at-Tijani yang mencapai dua kedudukan tertinggi (Qutb al-Aktab dan Al-Khatm al-Wilayab) ${ }^{31}$ adalah manifestasi dari tradisi ini. Dua kedudukan tertinggi itu sejajar dengan kedudukan Nabi Muhammad saw dan hubungannya dengan nabi-nabi dan wali-wali. Padahal Nabi Muhammad saw adalah penutup bagi para Rasul sebelumnya, dalam pengertian bahwa beliau adalah Rasul terakhir dan menduduki derajat tertinggi di antara seluruh Rasul yang pernah diutus ke dunia dan tidak ada Nabi yang diutus sesudah beliau. Sedang Ahmad at-Tijani mengaku sebagai wali penutup dalam pengertian bahwa ia membawa kesempurnaan kewalian (wilayab) untuk seluruh wali, baik sebelum maupun sesudahnya. Jadi, kalau ada wali sesudahnya, maka derajat wali itu tidak setinggi Ahmad at-Tijani. Bahkan pengikut tarikat ini membagi Wali Khatm menjadi dua: khatm auliya ammah dan khatm auliya khassah. Khatm auliya ammah adalah Saidina Isa Ibnu Maryam a.s. karena

${ }^{30}$ Hasil wawancara dengan Ahmad Nawawi Barabai, H. Suni Negara, serta H. Abu Samah dan H. Tajudinnor Banjarmasin dan A. Syinqithy Djamaluddin, op. cit., h. 91-93.

${ }^{31} \mathrm{Al}$-aqtab artinya beberapa wali qutub. Beberapa wali qutub itu disebut qutbul balad, qatbul jamak dan qatbul khatm. Al-aqtab itu zahir dalam satu masa dan dari beberapa wali qutub itu ada qutub yang tertinggi di zaman itu disebut wali al-khatm. al-Khatm atau auliya adalah orang yang menjadi standar kewalian. Ia adalah ujung dari hirarki tertinggi dan sekaligus penutup garis kewalian pada zamannya. Ia mencapai kedudukan ini tanpa diketahui oleh orang dengan kemampuan (spiritual) yang tak tertandingi dan tergantikan. Kalau ada wali sesudah itu, wali itu adalah pengikut, sahabat atau pembaru untuknya. Sedangkan khatm al-Auliya adalah wali tertinggi mahabbahnya sejak zaman nabi Adam as sampai akhir zaman dan terbanyak mendapatkan limpahan karunia. Lihat Husaini Hasan at-Thabai At-Tijani, Akwa Adallati wal Barabin, (Mesir: Maktabah al-Qahirah al-Azhar, t.th), h. 47., serta Mahyuddin Ibnu Arabi, Futubatu al-Makiah, Jilid III, (Beirut: Dar al-Fikr, 1994), h. 87. 
beliau menjadi tanda dekatnya hari kiamat dan khatm auliya khassah adalah Syekh Ahmad at-Tijani karena ia wali yang menghimpun semua kesempurnaan yang ada pada para wali dan yang memelihara semuanya.

Tampaknya Ahmad at-Tijani terpengaruh oleh teosufinya Ibn al-Arabi seorang sufi termasyhur dari Andalusia abad ke-13 M, konon pernah mengaku bahwa dirinya telah mencapai kedudukan Quthb al-Aqthab dan Khatm al-Wilayah. Hal itu sejalan dengan pengakuan Ibn al-Arabi bahwa khatm al-wilayah alMubammadiyah nanti adalah seorang bangsawan asal Arab, hidup sezaman dengannya di Fez. ${ }^{32}$

Para ulama berbeda pendapat tentang apakah seorang wali boleh diketahui kewaliannya atau tidak. Sebagian mereka mengatakan hal itu tidak boleh diketahui, karena seorang wali selalu melihat dirinya dengan rendah hati, jika terlihat sedikit saja dari keramatnya, dia khawatir akan menipu dirinya. Hal itu dikarenakan dia selalu merasa takut jatuh dari kedudukan kewaliannya dan bisa membawa akibat yang berbalik kepadanya. Sebagian yang lain mengatakan bahwa seorang wali boleh diketahui bahwa dirinya adalah wali. Mereka ini tidak menjadikan syarat kewalian. Menurut mereka yang terpenting adalah tandatanda wali itu sendiri. Tanda-tanda wali ada tiga, yaitu: ia selalu sibuk dengan Allah, pelariannya selalu kepada Allah, dan tujuannya hanya kepada Allah. ${ }^{33}$

Orang sufi membagi wali menjadi beberapa bagian, ada yang disebut wali al-gauts mempunyai kemauan sendiri dalam segala sesuatu dalam dunia ini, dan ada empat wali qutub memegangi empat pojok dunia ini atas perintah wali al-gauts. Ada wali abdal yang tujuh, masing-masing mempunyai kekuasaan di satu benua dari tujuh benua atas perintah wali al-gauts ada wali mujabak, yang memiliki kekuasaan di kota-kota setiap wilayah di kota. Demikian seterusnya. Jaringan wali-wali internasional ini menguasai makhluk dan mereka mempunyai dewan tempat berkumpul, yaitu di Gua Hira, setiap malam mereka melihat takdir. Dunia perwalian (sufi) itu adalah dunia khurafat (kepercayaan yang menyeleweng dari kemurnian Islam, karena mereka telah mengklaim kewalian itu, meletakkan kain kuning di atas kuburan, mengeruk keuangan orang-orang awam, membangun kuburan dan membuka kotak-kotak amal/nazar yang

${ }^{32}$ Hasil wawancara dengan Ibrahim di Anjir Kota Lihat Husaini Hasan at-Thabai AtTijani, Akwa Adallati ..., h. 28-30., serta Mahyuddin Ibnu Arabi, Futubatu al-Makiah..., h. 87.

${ }^{33} \mathrm{Abu}$ Qasim Abdul Karim Hawazin al-Qusyairi An-Naisaburi, Risalah Qusyairiyah fil Ilmu at-Tasawuf, op.cit, h. 261-263. 
dijaga oleh karyawan yang bertugas mengawasi kotak. Petugas dibayar dari penghasilan tersebut yang diperoleh dengan jalan yang tidak benar. ${ }^{34}$

Hal tersebut berbeda dengan kewalian dalam Islam yang ditegakkan di atas agama dan takwa, amal saleh, ibadat kepada Allah dan membutuhkan pertolongan Allah. Sebenarnya wali tidak bisa menguasai dirinya sendiri (untuk mendatangkan manfaat dan mudarat) maupun untuk menguasai orang lain. Allah swt berfirman, yang artinya: "Katakanlah, sesungguhnya aku tidak kuasa mendatang suatu kemudaratan pun kepadamu dan tidak (pula) suatu kemanfaatan". (Q.S. al-Jinn : 21).

Wali Allah tidak terbatas jumlahnya, siapa saja yang taat kepada Allah dan mengikuti jejak Rasul-Nya akan dijadikan Allah wali. Pangkat wali ini terbuka bagi setiap orang, seperti dikemukakan oleh Hamka: "Semua orang dapat mencapai derajat waliullah itu, asal dipenuhi persyaratannya". ${ }^{35}$

Memperhatikan kewalian di atas, wajar Ahmad at-Tijani mengaku sebagai wali, akan tetapi yang sering dipersoalkan adalah wali yang mendapat kedudukan sebagai Khatm al-Wilayah sesudah Nabi Muhammad saw. Dalam Islam, setelah Nabi Muhammad saw ada waliullah, akan tetapi tidak ada pangkat atau embel-embel tambahan seperti wali penutup/tertinggi maupun bagian-bagian wali tertentu. Semua orang bisa mencapainya asalkan memenuhi persyaratan. Persyaratan seseorang menjadi wali diantaranya beriman dan bertakwa kepada Allah, selalu mendekatkan diri kepada Allah, mengerjakan segala yang difardukan dan disunatkan, tidak rakus kepada dunia dan berakhlak mulia. ${ }^{36}$

Dengan mengaku sebagai wali tertinggi atau wali khassah dari wali-wali lain dan melepaskan ikatannya dari tarikat-tarikat lain, Ahmad at-Tijani secara implisit menempatkan tarikatnya lebih istimewa dari tarikat lain. Pada gilirannya, klaim ini berubah menjadi semacam doktrin yang melarang pengikut tarikat Tijaniyah berdoa untuk atau memohon berkah dari wali-wali lainnya, seperti menziarahi mereka karena takut madat/syirik, mewajibkan pengikutnya mengikatkan hati sepenuhnya kepada Syekhnya, berarti tidak seorang pengikut boleh merangkap keanggotaan dengan tarikat lain.

\footnotetext{
${ }^{34}$ Hartono Ahmad Jaiz, Gusdur Wali? Menundukean Tasawnf, (Jakarta: Darul Falah, 2000), h. 90-91., dan Yusril Ali, Membersibkan Tasawuf dari Syiah, Bidah, dan Khurafat, Jakarta: Yayasan al-Amin, t.th), h. 114-115.

${ }^{35}$ Hamka, Tasawuf Perkembangannya dan Pemurniannya, (Jakarta: Pustaka Panjimas, 1984), h. 108.

${ }^{36}$ M. Faiz al-Math, Puncak Rohani Kaum Sufi, Khazanab Perjalanan Spiritual Tokob-Tokoh Islam Yang Terpendam, (Jakarta: Pustaka Proressif, t.th), h. 175-176.
} 
Satu lagi ciri yang membedakan tarikat Tijaniyah dengan tarikat-tarikat lainnya, adalah genealogi atau silsilah spiritual. Lazimnya dalam tradisi sufi, suatu tarikat mempunyai daftar panjang para syekh. Daftar ini menunjukkan adanya hubungan spiritual antara seorang Syekh dengan pendiri tarikat itu melalui al-Junayd atau al-Busthami dan selanjutnya melalui Ali atau Abu Bakar bersambung kepada Nabi Muhammad saw. Silsilah ini berfungsi sebagai legitimasi bahwa ajaran dan wirid tarikat yang bersangkutan dianggap benarbenar otentik berasal dari Rasulullah saw dan juga dari Allah. Kesinambungan ini pula yang dianggap "jaminan” untuk mendapat berkah. Dalam tarikat Tijaniyah tidak ada silsilah. Apabila ada, silsilah itu lebih pendek dari yang lazimnya dikenal dalam dunia sufi. Sebab, antara Ahmad at-Tijani pendiri tarikat Tijaniyah dengan Rasulullah saw tidak ada guru lain sebagai pembimbing. Ahmad at-Tijani mengaku "dibaiat langsung" oleh Rasulullah saw.

Tarikat Tijaniyah juga mengajak pengikutnya meninggalkan merokok karena menurut mereka, merokok merupakan suatu najis, rokok mengandung nikotin, karena dalam setiap melaksanakan shalat, amalan atau membaca Alquran seseorang harus bersih dari bau mulut dan najis. Mulut yang bersih itulah yang diharuskan oleh tarikat ini dalam melaksanakan amalannya. Hal itu sejalan dengan ilmu kesehatan, secara patologis, merokok berhubungan dengan hiperplasia kelenjar mukus bronkus dan metaplasia skuausepitel saluran pernapasan, ${ }^{37}$ dan akan mengganggu kesehatan seseorang seperti timbulnya penyakit kanker paru-paru, kanker kandung kemih, dan penyempitan pembuluh darah sehingga mengakibatkan penyakit jantung, stroke dan lainlain. ${ }^{38}$ Bahkan menurut hasil penelitian di Amerika Serikat, akibat merokok lebih 350.000 orang telah meninggal dunia pertahun, baik di Amerika, Vietnam, dan Korea. ${ }^{39}$ Program tarikat Tijaniyah selain menghindarkan manusia dari berbagai penyakit yang ditimbulkannya, juga sejalan dengan program pemerintah Republik Indonesia. Misalnya melarang merokok agar masyarakat terhindar dari berbagai penyakit yang ditimbulkannya, diantaranya penyakit jantung, stroke, kanker paru-paru dan kandung kemih, dan impoten.

Menurut pengakuan pengikut tarikat Tijaniyah ajaran tarikat ini tidak mendapat pertentangan antara syariat dan tarikat, keduanya saling berkaitan

\footnotetext{
${ }^{37}$ Soeparman dan Sawarno, Ilmu Penyakit Dalam, Jilid II, (Jakarta: FKUI, 1998), h. 755.

${ }^{38}$ Mulyadi Hartono, Mencegah dan Mengatasi Asteoporosis, (Jakarta : Puspa Swara, 2001), h. $43-44$.

${ }^{39}$ Robin S. dan Kumar, Potologi I, (Jakarta: Kodokteran EGC, 1995), h. 325.
} 
satu sama lain. Perbedaan antara syariat dan ajaran tasawuf adalah dalam menerima ajaran. Setelah Nabi wafat, umat Islam menerima ajaran agama Islam dari Alquran dan sunah, serta ijmak. Umat ini yang terjaga untuk melakukan ijtihad yang belum tentu benar atau salah. Masing-masing ulama berijtihad sendiri, misalnya, kaum sufi menentukan sumber ajaran agama dari setiap yang berhembus dan bergerak, maka bermunculan tarikat dengan wiridnya yang berbeda-beda.

\section{Penutup}

Berdasarkan uraian yang telah dipaparkan di atas, dapat diambil kesimpulan sebagai berikut:

Pertama, tarikat Tijaniyah mulai berkembang di Kalimantan Selatan pada tahun 1995 dibawa oleh K.H. Ahmad Anshari dari Kota Banjarmasin. Dari kota ini Tarikat Tijaniyah terus menyebar ke seluruh Kalimantan Selatan, bahkan ke Kalimantan Tengah dan Pulau Bangka. Tarikat ini memiliki 21 majelis taklim dan 4 zawiyah, dengan pengikut kurang lebih 15.000 orang dan mengangkat tiga orang muqaddam atau badal, yaitu K.H. Suni, Kiai Ahmad Nawawi dan Kiai Ibrahim. Cepatnya perkembangan tarikat ini tidak terlepas dari berbagai macam sistem dan metode yang mereka gunakan, yaitu: kesederhanaan dan ketegasan aspek ritual, memberikan kebebasan bagi calon pengikut terlebih dahulu mempelajari dan mengamalkan wirid tarikat, memiliki bentuk struktur organisasi keagamaan dan sosial, menganut prinsip tasamuh atau toleransi, melaksanakan bimbingan/pengajian, menganjurkan pengikut berdakwah atau mengajak orang agar masuk tarikat, dan menerapkan persyaratan dan aturan yang wajib ditaati oleh pengikutnya.

Kedua, amalan atau wirid tarikat Tijanyah terdiri dari wirid lazim, wirid wazifah dan wirid haylalah, ketika wirid itu pada dasarnya sangat sederhana, tegas dan mudah diamalkan.

Ketiga, tarikat Tijaniyah di Kalimantan Selatan di bawa K.H. Ahmad Anshari dengan silsilah diterima dari K.H. Badri Masduqi dari Syekh Idris al-Iraqi dari Syekh Muhammad Hafiz al-Misri dari Sayyid Assyarif Ahmad Sukayrij al-Marakusyi dari Sayyid Assyarif Ahmad al-Badalawi at-Tijani dari al-Gaust Asshamadaani Sayyidi Assyarif Ali at-Tamasini at-Tijani dari Penghulu seluruh Awliya dari Munriddul Aqwast Wal Aqthaab Maulana Ahmad bin Muhammad bin Muhammad at-Tijani menerima dari Al Habibul Akzam warasulul akram Muhammad bin Abdillah Sallalahu alaihi wa sallam secara yakzhah/dalam keadaan jaga, tidak dalam keadaan tidur dan mimpi. Silsilah 
yang diterima K.H. Ahmad Anshari diterima dari Syekh Idris al-Iraqi. Memperhatikan silsilah K.H. Ahmad Anshari adalah serumpun dan bertalian dengan tarikat Tijaniyah di Jawa dan di Mekkah. Silsilah itu merupakan jaminan bagi pengikutnya untuk masuk surga tanpa dihisab dan wirid yang diamalkan menjadi sah dan beberkah. 


\section{Daftar Pustaka}

Ali, Yusril, Membersibkan Tasawuf dari Syiah, Bidah, dan Khurafat, Jakarta, Yayasan al-Amin, t.th.

Arabi, Mahyuddin Ibnu, Futubatu al-Makiah, Jilid III, Beirut, Dar al-Fikr, 1994.

al-Bantani, Muhammad ibn Umar an-Nawawi, Tanqibul Qaul al-Hatsists, Bandung, Trigenda Karya, 1994.

Bearman PJ., dkk, (et-al). The Encyclopedia of Islam, Leiden, Bruth, 2000.

Dahlan, Sayid Abdullah, Tanbihul Ghafil wa Irsyadul Mustafidi'i Aqil, Terj. Bahrun Abu Bakar, Tarekat Tijaniyah suatu Pertanyaan, Jakarta, Andamera Pustaka. 1987.

Djamaluddin, A. Syinqithy, Kunci Rabmat Ilabi, Jawa Timur, Pustaka at-Tijani, 2000.

Fathullah, Fauzan, Tafi al-Quthbul Maktum Sayidul Awliyaa Syekh Ahmad at-Tijani dan Tarekatnya at-Tijani, Banjarmasin, Ikatan Pengamal Kalimantan, t.th.

Hamka, Tasawuf Perkembangannya dan Pemurniannya, Jakarta, Pustaka Panjimas, 1984.

Hartono, Mulyadi, Mencegah dan Mengatasi Asteoporosis, Jakarta, Puspa Swara, 2001.

Jahja, M. Zurkani, Syariat, Sufisme dan Tarekat (Refleksi Terhadap Beberapa Kasus di Kalimantan Selatan), Banjarmasin, IAIN Antasari, 1993.

Jaiz, Hartono Ahmad, Gusdur Wali? Menundukkan Tasawuf, Jakarta, Darul Falah, 2000.

al-Jauziyah, Ibnu Qayyim, Al-Fawaid, Terj. Munirul Abidin, Al-Fawaid Menuju Pribadi Takwa, Jakarta, Pustaka al-Kausar, 2000.

al-Math, M. Faiz, Puncak Rohani Kaum Sufi, Khazanah Perjalanan Spiritual TokohTokoh Islam Yang Terpendam, Jakarta, Pustaka Proressif, t.th.

An-Naisaburi, Abu Qasim Abdul Karim Hawazin al-Qusyairi, Risalah Qusyairiyah fil Ilmu at-Tasawnf, Beirut, Dar al Fikr, t.th.

Robin S. dan Kumar, Potologi I, Jakarta, Kodokteran EGC, 1995.

Soeparman dan Sawarno, Ilmu Penyakit Dalam, Jakarta, FKUI, 1998. 
At-Tijani, Husaini Hasan at-Thabai, Akwa Adallati wal Barabin, Mesir, Maktabah al-Qahirah al-Azhar, t.th.

At-Tijani, Muhammad al-Arabi an-Saih asy Syurqi Umar, Bughyatul Mustafid Lisyarthi Munyatil Murid, Beirut, Dar al Fikr, 1973 M/1393 H.

At-Tijani, Muhammad bin Abdullah bin Husaini asy-Syafi'i at-Tasfawi, Fathur Rabbani. Karakasan, Makhad Badri al-Daja al-Islamiyah, t.th.

Wahib, Tasawnf dan Transformasi Sosial (Studi Atas Pemikir Tasawnf Hamka), Surabaya, IAIN Sunan Ampel, 1997.

Yaqub, Hamzah, Tingkat Ketenangan dan Kebabagiaan Muslim (Tasawuf dan Takarrub), Jakarta, Atisa, 1992.

Zulkifli, Neo Sufisme di Indonesia Pemikiran dan Perkembangannya. Palembang, Puslit IAIN Raden Fatah, 1997. 


\section{Mengenal ajaran tasawuf Tarikat Tijaniyah}

Tarikat adalah jalan atau petunjuk dalam melaksanakan suatu ibadah sesuai dengan ajaran yang dibawa oleh Rasulullah saw. dan dicontohkan oleh beliau, para sahabat, tabi'i dan tabi' tabi'in. ${ }^{40}$ Umarie Barmawi mengungkapkan pengertian tarikat adalah jalan atau sistem yang ditempuh menuju keridhaan Allah semata, sedang usaha menempuh jalan itu bernama suluk, dan orangnya bernama salik. ${ }^{41}$ Laily Mansur menyatakan tarikat merupakan usaha pencapaian pengalaman batin yang dilaksanakan dengan cara dan aturan praktis, penuh disiplin dengan tujuan mendekatkan diri kepada Allah di bawah bimbingan seorang syekh. ${ }^{42}$

Jadi tarikat adalah suatu cara atau jalan yang ditempuh oleh para ahli tasawuf atau kaum mutasawwifin untuk mencapai tujuan, sebagaimana yang dijelaskan oleh Syekh Zainuddin bin Ali "tarikat adalah menjalankan amal dengan lebih berhati-hati dan tidak memilih kemurahan (keringanan) syara' seperti sifat wara' serta ketetapan hati yang kuat seperti latihan-latihan jiwa 43

Tarikat bermula dari tasawuf yang kemudian berkembang dengan berbagai macam paham dan aliran. ${ }^{44}$ Sedang pengertian Tasawuf itu sendiri secara umum adalah usaha untuk mendekatkan diri kepada Allah dengan sedekat mungkin melalui

\footnotetext{
${ }^{40}$ Muhamad Saifulllah,al- Aziz Senali, Tasawuf dan Jalan Hidup bagi Para Wali, Gresik, Jawa Timur, Putra Pelajar, 2000, h. 32.

${ }^{41}$ Bermawi Umarie, Sistematika Tasawuf, Solo, Ramadhani, 1987, h. 116.

${ }^{42}$ H.M.Laily Mansur, Tasawuf Islam, mengenal Aliran dan Ajaran, Unlam Press, Banjarmasin, 1992, h. 103-104

${ }^{43}$ Muhamad Saifullah al-Aziz Senali, Tasawuf dan Jalan hidup bagi para Wali, Gresik Jawa Timur, Putra Pelajar, 2000, h. 32.

${ }^{44}$ PPTA IAIN Sumatera Utara, Pengantar Ilmu Tasawuf, Medan,PPTA IAIN, 1983, h. 274.
} 
kesucian rohani dalam memperbanyak ibadah. ${ }^{45}$ Untuk mendekatkan diri kepada Allah dalam tarikat diperlukan adanya bimbingan seorang guru/syekh, sebab bagi yang beribadah tanpa bimbingan guru/pembimbing, berarti dia dibimbing orang ketiga, orang ketiga dimaksud adalah setan.

Tarikat Tijaniyah disampaikan pertama kali oleh Syekh Ahmad al-Tijani. (w. $1230 \mathrm{H} / 1815 \mathrm{H})^{46}$ Tarikat ini bermula dari Berber Al-jazair dan menyebar dari al-Jazair ke selatan Sahara, terus masuk ke Sudan bagian Barat dan Tengah, Mesir, Senegal, Afrika Barat, Nigeria, dan bahkan tarikat ini sudah diperkenalkan sampai ke Amerika Barat dan Utara. ${ }^{47}$ Tijaniyah termasuk tarikat muktabarah yang diakui keberadaan dan kebenarannya di Indonesia $^{48}$.

Nama Tijaniyah ini dinisbatkan kepada keluarga ibunya, dan disebut juga dengan tarikat al-Ahmadiyah ${ }^{49}$, tarikat ini tidak diketahui secara pasti kapan sampai ke Indonesia dan siapa yang membawanya. Namun yang tercatat dalam sejarah bahwa ditahun 1928 telah terjadi gerakan (kegiatan tarikat) di Cerebon. Seorang Arab yang tinggal di Tasikmalaya bernama Ali bin Abdullah al-Thayyib al-Azhari berasal dari Madinah menulis

${ }^{45}$ Projodikoro, Jama'ah pengajian tarikat Islamiyah LempuyanganYogyakarta dalam Jurnal Penelitian Agama no 15 Th VI, Januari-April 1997, Yogyakarta, Balit P3M IAIN Sunan Kalijaga, 1997, h. 13.

${ }^{46}$ H.M. Laily Mansur, Ajaran dan Teladan Para Sufi, Jakarta, PT Raja Grafindo Persada, 1999, h. 285.

${ }^{47}$ Syekh Fadlullah Haeri, $T$ he Elements of Sufism, terj. Belajar Mudah Tasawuf, oleh Muhamad Hasyim Assegaf, Jakarta, PT Lentera Basritama, 1994, h. 29.

${ }^{48}$ Musyawarah nahdhiyyin di Pekalongan Jawa Timur tanggal 26-28 Pebruari 2000 menetapkan bahwa ada 46 nama tarikat yang dianggap mu'tabarah, dan salah satunya adalah tarikat Tijaniyah.

${ }^{49}$ Muhammad bin Abdullah bin Husnain, Al-Fath al-Rabbany fii ma yahtaju ilaihi lMuriid al-Tijani, Surabaya, maktabah Sa'ad bin Nashir bin Nabhan, t.th.,h. 4. Lihat pada H. Abu Bakar Aceh, Pengantar Ilmu Tarikat, (uraian ttg Mistik), Solo, Ramadhani, cet x, 1994, h.374. 
sebuah kitab "Munyatul Murid", berisi tentang beberapa petunjuk dan ajaran Tarikat Tijaniyah. Juga di tahun 1934 dalam "Pragmenta Islamica" di Leiden terdapat hasil penyelidikan Dr. G.F. Pijper terhadap kegiatan tarikat Tijaniyah di Indonesia atau Cerebon. Dari bukti sejarah ini berarti tarikat Tijaniyah ini berada di Indonesia minimal sejak tahun 1928 tersebut.

Secara genetik Ahmad al-Tijani mempunyai hubungan darah dengan Nabi saw. ${ }^{50}$ mempunyai jiwa yang gemar terhadap ilmu, sehinggga tidak mengherankan dikemudian waktu ia menjadi sufi yang termasyhur dan berhasil dengan tarikatnya.

\section{A. Sekilas tentang sosok pribadi Syekh Ahmad al-Tijani.}

Syekh Ahmad al-Tijani adalah pendiri tarikat Tijaniyah, berasal dari Algeria (marokko) bernama lengkap Abu al-Abbas Ahmad bin Muhammad (Abi Amr) ibn Mukhtar bin Ahmad bin Salim bin al'id ibn Salim bin Ahmad ('Ulwani) ibn Ahmad bin Ali bin Abdullah bin Abbas ibn Abdul Jabbar bin Idris bin Ishak bin Zainal Abidin bin Ahmad bin Muhammad (al-Nafs alZakiyah) ibn Abdillah al-Kamil ibn Hasan al-Mutsanna ibn Hasan al-Sabth bin Ali bin Abi Thalib dari Fatimah al-Zahra binti Muhammad bin Abdullah Rasulullah saw. ${ }^{51}$ sedang dari pihak ibunya, Ahmad al-Tijani adalah Aisyah binti Jalil Abi Abdilllah Muhammad bin Sanusi at-Tijani al-Madhawi. Dari sinilah nama Tijani diambil, yaitu dari qabilah yang terkenal saat itu yaitu Tijanah. ${ }^{52}$

Dari silsilah keturunan di atas jelas terlihat bahwa Ahmad al-Tijani terambil dari Tijanah keluarga ibunya. Dan beliau dari pihak ayah adalah keturunan dari Hasan bin Ali bin Abi Thalib,

\footnotetext{
${ }^{50}$ Noer Iskandar al-Barsany, Tasawuf Tarikat dan Para Sufi, Jakarta, Srigunting Raja Grafindo Persada, 2001, h. 90.

${ }^{51}$ Muhammad bin Abdullah, op.cit., h. 7

${ }^{52}$ Ibid.
} 
artinya keluarga Ahmad al-Tijani masih keturunan ahli bait (keluarga Rasulullah saw.)

Ahmad al-Tijani lahir pada tahun $1150 \mathrm{H}(1737-8 \mathrm{M}) \mathrm{di}$ desa 'Ain Madhi. Kampung ini letaknya di Gurun Sahara bagian timur negara Magrib, yaitu di sebelah selatan al-Jazair. ${ }^{53}$

Ahmad al-Tijani pada awalnya berguru kepada orang tuanya dan guru-guru di daerahnya. Di usia tujuh tahun Ahmad al-Tijani sudah hafal al-Qur'an secara keseluruhan. Pada tahun $1166 \mathrm{H}$. Ayah dan ibunya meninggal pada hari yang sama dikarenakan wabah (cacar/panas), jadilah dia sebatangkara padahal usianya masih sangat muda (16 tahun). Sepeninggal orang tuanya Ahmad al-Tijani tinggal bersama saudara ibunya sampai usianya 21 tahun. Setelah itu Ahmad al-Tijani mengembara mencari ilmu keberbagai daerah. Di tahun $1186 \mathrm{H}$ dia berangkat ke Mekkah untuk menunaikan ibadah haji dan berziarah ke makam Rasulullah saw. di Madinah. Di kota ini Ahmad al-Tijani banyak berguru menimba ilmu-ilmu agama, juga ilmu yang berkaitan dengan ilmu rahasia bathin (asrar). Berkaitan dengan ilmu asrar ini Ahmad al-Tijani berguru kepada Muhammad bin Abdul Karim al-Samman, pendiri tarikat Sammaniyah.

Ketika Ahmad al-Tijani berusia 50 tahun $(1200 \mathrm{H})$ beliau bertemu lagi dengan Rasulullah saw dalam kasyfnya dan menyempurnakan amaliah/wiridan yang pernah diberikan, yaitu dengan menambahkan seratus kali zikir Hailalah. Ungkapan Rasul kepada Ahmad al-Tijani tersebut berbunyi demikian sebagaimana yang termaktub di dalam kitab Fathur Rabbany, yaitu :

\footnotetext{
${ }^{53}$ H.M.Laily Mansur, loc.cit.
} 
Semenjak itu Ahmad al-Tijani mengajarkan wirid, zikir, shalawat, istigfar dan do'a yang diterimanya dari Rasulullah saw. kepada murid-muridnya. Pada tahun $1213 \mathrm{H}$, Ahmad alTijani pergi dan pindah ke kota Fez (Marokko) dan menetap disini mengajarkan tarikatnya. Akhirnya di usianya yang ke 80 tahun bertepatan tanggal 17 Syawal $1230 \mathrm{H}$ atau 22 Sept 1815 $M$ dia meninggal pada hari Kamis, sesudah shalat Subuh, berbaring di bahu kanan dan dengan tenang menghadap Allah. Dan dimakamkan di Fez. ${ }^{54}$

\section{B. Ajaran Tarikat Ahmad al-Tijani.}

Berbeda dengan tarikat-tarikat lain, tarikat Tijaniyah ini tidak mempunyai silsilah tarikat, sebab sebagaimana telah diungkapkan di atas bahwa Ahmad al-Tijani menerima ini semua langsung dari Rasulullah saw. Ajaran yang sederhana dan relatif mudah. Sebab tujuannya adalah mendekatkan diri kepada Allah, memperoleh ampunan dan ridha-Nya.

Tarikat Tijaniyah tidak mengenal mursyid, tapi mereka mengenal istilah muqaddam dan khalifah. Pengikutnya tidak dibenarkan berpolitik praktis, sebab hal itu identik dengan permusuhan, persaingan atau kebencian. Hidup bersih dan makanan halal adalah sesuatu hal yang harus diprioritaskan, karena kebersihan jasmani berpengaruh kepada bathin/rohani. Untuk menghasilkan hati bersih, makanan serta faktor pendukung (finansial) pun harus bersih dan halal. Tanpa itu tabir ilahiyah sulit terungkap. ${ }^{55}$

Dalam Tarikat Tijaniyah ada beberapa persyaratan penting yang harus dipenuhi dan diperpegangi oleh pengikutnya, yaitu :

\footnotetext{
${ }^{54}$ Muhammad bin Abdullah, op.cit., h. 6-10.

${ }^{55}$ Republika, terbit hari Jum'at, 31 Mei 2002.
} 
1. Melazimkan shalat fardhu dalam waktunya dengan memelihara syarat, rukun dan segala adabnya yang sunatsunat. Utama sekali berjamaah.

2. Taqwa kepada Allah dengan zahir dan batin sesuai kemampuan. Jika terjadi pelanggaran syar' $i$ wajib segera bertaubat kepada Allah.

3. Tidak ziarah untuk minta madad rohani (seperti minta do'akan) kepada waliullah yang bukan dari Tijaniyah dan sahabat Rasulullah saw. baik yang sudah mati maupun yang masih hidup. Tetapi wajib memuliakan waliullah (jangan diremehkan).

4. Tidak mengumpulkan tarikat ini dengan tarikat lainnya.

5. Bersedia mengamalkan ajaran tarikat ini sampai akhir hayatnya $^{56}$

Disamping persyaratan diatas juga ada beberapa hal yang berkaitan dengan kesempurnaan pengikut tarikat ini, yaitu :

a. Yakin bahwa Ahmad al-Tijani melihat atau bertemu Rasululllah saw dalam keadaan sadar, jaga, bukan melalui mimpi.

\footnotetext{
56 Catatan (nuskhah) wirid tarikat Tijaniyah yang disusun oleh khadam Ahmad al-Tijani wilayah Kalimantan. H.Ahmad Anshary sanad tarikatnya sampai pada Syeh Ahmad alTijani. Rangkaian sanad tersebut adalah : H.Ahmad Anshary dari al-alimul allamah Sayyid Idris bin Muhammad al-'abid al-Iraqy al-Magriby, diMakkah al-Mukarramah dari Syeh Ahmad al-Sukairij, dari syeh Sayyid Ahmad al-Abdalawi, dari al-qutb al-Syarif al-Hajj alTamasiny, dari Syaihuna al-qutb al-Kamil al-Rabbany Sayyidul Awliya wal Aqthab Maulana Ahmad bin Muhammad al-Hasani al-Tijani, dari Sayyid al-Wujud Rasulullah saw ketika Syeh Ahmad al-Tijani tidak tidur bertemu langsung dengan Rasulullah saw.
} 
b. Hadirnya Rasulullah saw dan sahabat serta Ahmad alTijani ketika membaca Jauharat al Kamal dihitungan bacaan kali ketujuh.

c. Menggunakan harum-haruman ketika membaca Jauharat al-Kamal dan dianjurkan berkelompok sekitar 6 orang dengan duduk diatas hamparan kain.

d. Haruslah berwudhu sebelum membaca Jauharat al-Kamal.

e. Suci dari hadas besar dan kecil ketika membaca wirid

f. Membaca tasbih dikala ruku' dan sujud disyaratkan tiga kali dan harus dibaca secara tartil.

g. Membaca basmalah dengan jelas (agak nyaring) dibacaan al-fatihah di dalam shalat fardhu.

h. Ahmad al-Tijani adalah al-Qutb al-Maktum wa al-Khatim al-Muhammadiy al-Ma'lum.

i. Penutup para wali.

j. Pancaran Ilahi (al-faidh) memancar dari zat Sayyid alWujud Muhammad saw terus ke Ahmad al-Tijani untuk seluruh makhluk.

k. Membaca salawat fatih sekali sebanding dengan enam kali membaca al-Qur'an

1. Larangan menziarahi wali-wali lain dengan maksud mengambil wirid darinya. ${ }^{57}$

Dalam Tarikat Tijaniyah terdapat tiga pokok amalan wirid (bacaan yang diamalkan/ dibaca secara rutin), yaitu : wirid Lazimah, Wazifah dan Hailalah.

1. Wirid Lazimah ${ }^{58}$

\footnotetext{
${ }^{57}$ Muhammad bin Abdullah, op.cit., h. 10-38.
} 
Wirid lazimah, dilaksanakan setiap pagi hari mulai selesai shalat subuh sampai datangnya waktu dhuha, dan sore hari, mulai selesai melaksanakan shalat ashar sampai datangnya waktu isya dengan praktik wirid sebagai berikut:

a. Muqaddimah (pendahuluan). Bacaannya yaitu membaca al-fatihah dihadiahkan buat Rasulullah saw. dan Ahmad al-Tijani lalu salawat fatih masing-masing satu kali, selanjutnya membaca tasbih, salam dan tahmid.

b. Membaca Istigfar sebanyak seratus kali.

c. Membaca salawat kepada Nabi dan keluarganya sebanyak seratus kali.

d. Membaca zikir, sebanyak seratus kali.

e. Khatimah (penutup). Bacaannya yaitu al-fatihah dan salawat fatih satu kali, ayat perintah bersalawat, yaitu ayat ke 56 surat al-Ahzab dan do'a.

Ahmad al-Tijani menganjurkan do'anya sebagai berikut

\section{Allahumma....}

Do'a tersebut menunjukkan bahwa Ahmad al-Tijani dalam mendidik murid, sejak langkah awal agar tidak mengandalkan kemampuan amalnya, akan tetapi lebih bertumpu pada keluasan dan kebesaran rahmat Allah.

Rangkaian wirid lazimah yang dikemukakan di atas, yang menjadi rukunnya hanyalah istigfar, salawat dan zikir, masing-

\footnotetext{
${ }^{58}$ Wirid adalah zikir atau do'a yng dibaca secara rutin. Lazimah adalaah wirid dasar bagi setiap pengikut tarikat Tijaniyah yang mesti dilaksanakan.
} 
masing 100 kali' sedangkan bacaan lainnya termasuk dalam keutamaan (al-fadhail).

Dalam Jawahir al-Ma'ani dikatakan bahwa tiga bentuk wirid tersebut merupakan satu kesatuan yang utuh, dalam arti masing-masing melengkapi satu sama lain. Bacaan istigfar misalnya dimaksudkan atau berfungsi membersihkan diri dari kotoran maksiat. Sebab pada dasarnya tujuan masuk tarikat ialah mendekatkan diri kepada Allah swt. ${ }^{59}$ Oleh karena itu terlebih dahulu murid harus beristigfar sebagai pembersih dan pensuci dosa.

Selanjutnya bacaan salawat dimaksudkan untuk mendekatkan diri kepada makhluk yang dicintai Allah swt yaitu Nabi Muhammad saw. beliau adalah makhluk yang mendapat gelar habib Allah. Allah memerintahkan umat beriman agar membaca salawat kepada Nabi Muhammad saw. begitu pula para malaikat juga diperintahkan untuk bersalawat ${ }^{60}$ atas Nabi Muhammad saw. sebagaimana yang termaktub dalam surat alAhzab ayat 56.

Ayat diatas menunjukan bahwa posisi Nabi Muhammad saw adalah makhluk yang diistemewakan oleh Allah swt. Ahmad al-Tijani menyebutnya sebagai makhluk yang paling ma'rifah (mengenal Allah) dan paling dekat pada Allah swt. ${ }^{61}$ Karena itu untuk menghadap dan menuju Allah swt terlebih dahulu murid harus mendekatkan diri kepada beliau dengan cara membaca salawat. Selain itu membaca salawat merupakan sarana untuk meraih rahmat Allah swt.

\footnotetext{
${ }^{59}$ Ali Harazim, Jawahir al-Ma'ani wa Bulug al-Ma'ani, (Mesir, Musthafa al-Babi alHalabi, 1985), juz 1, h. 102

${ }^{60}$ Salawat dari Allah adalaah limpahan rahmat-Nya dan salawat dari malaikat adalah istigfar. Lihat: At-Tirmizi, Sahih al-Tirmizi, (Semarang : Maktabat waa Matba'at Putra Semarang, t.th.), Juz I, h.303.

${ }^{61}$ Ali Harazim, op.cit., juz I, h. 197.
} 
Adapun bacaan zikir la ilaha illa allah, dibaca oleh murid setelah bersih dan suci melalui bacaan istigfar dan setelah mendekatkan diri kepada pembimbing utama, yakni Nabi Muhammad saw., selanjutnya ia menuju benteng Allah swt dengan zikir melalui bacaan la ilaha illa Allah.

Apabila dirujuk pola istigfar yang diajarkan oleh Nabi Muhammad saw. sebagaimana yang terdapat dalam hadis-hadis sahih, maka akan ditemui dua pola istigfar. Pertama diakhiri kalimat wa atubu ilaihi (aku bertobat kepada Allah), dan kedua, yang tidak diakhiri dengan kalimat itu.

Dengan melihat kepada dua pola istigfar yang terdapat di dalam hadis-hadis Nabi saw, maka amalan Tarikat Tijaniyah mempergunakan pola yang kedua, yaitu yang tidak disertai kalimat tersebut. Dalam Fath al-Rabbani dikatakan bahwa hal ini merupakan upaya penyelamatan diri dari dosa yang timbul dari bacaan istigfar itu sendiri, sebab menurutnya, tambahan kalimat tersebut mengandung arti bahwa orang yang membaca istigfar tersebut telah mengklaim dirinya sebagai orang yang melaksanakan taubat. Apabila dalam kenyataannya ia tidak melaksanakan taubat dengan sungguh-sungguh, misalnya ia tetap melaksanakan maksiat kepada Allah, dengan sendirinya secara tidak disadari ia telah melakukan dosa dari dua sisi. Pertama, dosa dari perbuatan maksiat itu sendiri, dan kedua dosa dari bacaan istigfarnya. Lain halnya dengan pola istigfar tanpa kalimat wa atubu ilaihi, ia tidak mempunyai beban apa-apa dari bacaannya, sebab ia hanya minta ampun kepada Allah. ${ }^{62}$ Yang dimaksud dengan istigfar adalah membersihkan diri dari kotorankotoran maksiat hati, dan dari kotoran tingkah laku lahiriah yang menyimpang dari aturan syari'at. ${ }^{63}$

\footnotetext{
${ }^{62}$ Muhammad bin Abdullah, op.cit., h. 70

${ }^{63}$ Ali Harazim, op.cit., juz II, h.9
} 
Pembacaan istigfar menurut Ahmad al-Tijani sudah mengandung pengertian melaksanakan taubat, sebab taubat itu menurut beliau mengembalikan diri dari kekufuran terhadap nikmat Allah, memperlihatkan sikap syukur kepada Allah dengan jalan melaksanakan segala perintah-Nya. Membersihkan diri dari sikap menyepelekan kewajiban syara', dan dari perbuatan yang dilarang oleh syara ${ }^{64}$ Dengan kata lain, taubat adalah kembali kepada Allah dengan jalan melaksanakan syari'at Islam. Sebab pada dasarnya perjalanan yang harus ditempuh oleh seorang murid menuju Allah sejak langkah awal sampai akhir harus menjalankan syari'at. Tidak mungkin seseorang sampai (wusul) kepada Allah tanpa dasar syari'at.

Untuk tercapainya pelaksanaan taubat, murid harus melaksanakan hal-hal berikut ini : melepaskan diri dari perbuatan dosa, merasa sedih terhadap perbuatan dosa yang dilakukannya, mempunyai maksud yang kuat untuk tidak kembali pada perbuatan maksiat, mempunyai tekad yang kuat untuk senantiasa beribadah kepada Allah dan merasa takut untuk tidak mensyukuri nikmat-Nya.

Untuk terwujudnya syarat taubat tadi, ada beberapa adab/ketentuan yang harus dilaksakan, yaitu : Menghindar dari orang-orang yang senantiasa melaksanakan perbuatan maksiat dan orang-orang yang mempunyai tabiat yang jelek, bahkan murid harus senantiasa bergaul dengan orang-orang yang taat melaksanakan kebaikan, menjauhi tempat-tempat keramaian yang tidak berguna dan tempat-tempat yang mengundang maksiat, dan tidak boleh banyak mengungkapkan kenikmatan nafsu syahwat. ${ }^{65}$

\footnotetext{
${ }^{64}$ Ibid.

${ }^{65}$ Sayyid Ubaidah,Mizab al-Rahmah fi al-Tarbiyah li al-tarikat al-Tijaniyah, (mesir; maktabah abd al-Hamid Ahmad, t.,th), h. 94
} 
Aspek bacaan salawat dalam wirid ini, kurang mendapat penekanan. Membaca salawat berfungsi li al-Tabarruk (untuk mendapatkan barkah) dan wasilah (perantara) supaya bacaan istigfar dan segala ketentuannya diterima oleh Allah swt. Ahmad al-Tijani mengatakan bahwa wasilah (perantara) yang utama untuk bisa wusul (sampai) terhadap Allah adalah nabi Muhammad saw. untuk dekat dengan Nabi Muhammad saw. adalah melalui bacaan salawat. Keyakinan ini didasarkan atas atsar (perkataan sahabat) Umar Ibnu al-Khattab yang menyatakan “ berkata Umar ibnu al-Khattab : Do'a seorang hamba ditangguhkan antara langit dan bumi, sampai dibacakan salawat kepada Nabi Muhammad saw."

Nabi Muhammad saw banyak mengungkapkan betapa penting dan keutamaannya membaca salawat, yang sasaran intinya adalah memohon rahmat Allah swt. Telah dikatakan bahwa "apabila seseorang membaca salawat (berdo'a) kepada Nabi Muhammad saw satu kali, maka Allah akan memberi rahmat sepuluh kali lipat" ${ }^{\prime \prime 6}$. Hal ini menunjukkan posisi Nabi Muhammad saw. di hadapan Allah swt. berbeda dengan makhluk-makhluk lainnya. Dengan kata lain beliau adalah makhluk yang diistemewakan Allah swt.

Sebagaimana halnya bacaan salawat, dalam wirid lazimah, bacaan zikir juga kurang mendapat tekanan. Dalam wirid ini zikir dimaksudkan untuk menyatakan taubat yang sungguh-sungguh, sehingga dengan ucapan lailahaa illa allah (tidak ada Tuhan selain Allah), murid seolah-olah mengatakan la yagfiru zuunuba illa allah (tidak ada yang menghapus dosa kecuali Allah). ${ }^{67}$ Selain itu, dengan mengamalkan zikir dalam wirid lazimah, diharapkan murid akan merasa sakit batinnya apabila tidak

\footnotetext{
${ }^{66}$ Muhyiddin Abi Zakaria,. Riyad al-Shalihin, (Bandung, al-Ma'arif, t.th.), h.200

${ }^{67}$ Sayyid Ubaidah, op, cit, h. 65.
} 
mempunyai kesempatan untuk berbuat baik, dan selanjutnya akan melakukan introspeksi (al-muhasabah) dengan harapan bisa memperbaiki keadaannya dan sekaligus memelihara taubatnya dengan segala amal syari'at. ${ }^{68}$

Di dalam tarikat Tijaniyah, murid dalam proses pendidikan ruhani (tarbiyah) harus menempuh perjalanan panjang dan penuh tantangan. Dalam tarikat Tijaniyah dikenal dua katagori murid. Pertama murid dalam katagori umum, dan kedua katagori khusus. ${ }^{69}$ Yang dimaksud murid dalam katagori umum adalah murid yang hanya diberi petunjuk-petunjuk umum mengenai amalan dasar, syarat dan peraturan yang terdapat dalam tarikat Tijaniyah, tanpa harus mengikuti aturan-aturan khusus dalam proses tarbiyah tarikat. Garis besarnya, murid dalam katagori ini hanya mempunyai tujuan mendapatkan barkah dan atau mendapatkan pahala dari amalan tarikatnya. Sedangkan yang dimaksud dengan murid dalam katagori khusus adalah mereka yang mengikuti aturan-aturan proses tarbiyah yang terdapat dalam tarikat Tijaniyah. Murid dalam katagori ini diarahkan untuk berada sedekat mungkin dengan Tuhan dan atau memperoleh cahaya ma'rifah. ${ }^{70}$

Penjelasan di atas, mengantarkan pada suatu pemahaman bahwa murid tarikat Tijaniyah dalam katagori pertama bisa dilakukan oleh umat Islam secara umum, yang terpenting mereka mempunyai keinginan untuk melaksanakan ketentuan-ketentuan umum tarikat ini, tanpa harus mengikuti disiplin latihan ruhaniyah secara khusus. Dengan demikian mereka hanya menyentuh permukaannya saja dari tarikat Tijaniyah. Sedangkan murid dalam katagori kedua, harus disiplin menjalankan latihan

\footnotetext{
${ }^{68}$ Ibid., h. 96.

${ }^{69}$ Ibid., h. 109.

${ }^{70}$ Ibid., h. 88
} 
ruhaniyah secara intensif, sebab mereka akan menembus kepada kedalaman tarikat Tijaniyah. Meski demikian, tarikat Tijaniyah dalam mendidik, mengarahkan dan memelihara muridnya yang dalam tradisi tarikat ini disebut ikhwan (saudara), atau ahl (keluarga) tarikat Tijaniyah, menpunyai syarat dan peraturan umum yang harus dipatuhi oleh setiap murid yakni mengosongkan amal wirid yang lain. Ahmad al-Tijani mengatakan bahwa muridnya haruslah terlebih dahulu mengosongkan amalan wirid yang telah diterima dari syekh atau guru yang lain. ${ }^{71}$

Suatu keharusan bagi pengikut tarikat Tijaniyah harus mengosongkan diri dari wirid yang lain. Yang dimaksud dengan "mengosongkan amal wirid yang lain" adalah bukan amal wirid yang terdapat dalam hadis-hadis Rasulullah saw. sebab amalanamalan wirid yang biasa di amalkan oleh Rasulullah saw sangat dianjurkan dalam tarikat Tijaniyah. Adapun yang perlu dikosongkan itu adalah amalan wirid tarikat yang telah didapat dari syekh/guru yang lain. Karena setiap tarikat punya amalanamalan. Ada yang punya kekhususan seperti tarikat Tijaniyah dan pula yang amalan yang umum dilakukan banyak orang sesuai dengan sabda atau hadis Rasulullah saw. Jelasnya tarikat Tijaniyah mengkhususkan untuk calon murid (pengikutnya) agar sebelum mengamalkan wirid tarikat Tijaniyah, amalan wirid yang dia punya sebelumnya harus ditinggalkan. ${ }^{72}$ Adapun wirid yang tidak termasuk ikatan tarikat seperti hizb dan wirid-wirid lain terutama salawat boleh diamalkan oleh ikhwan Tijani.

Di dalam Rimah, diungkapkan bahwa tarikat dan segala syarat dan peraturannya dan apa saja yang terdapat di dalamnya semuanya berdasarkan syariat. Adapun yang kelihatannya

\footnotetext{
${ }^{71}$ Muhammad ibn Abdillah, op.cit., h. 45.

${ }^{72}$ Umar al-Futi, Rimah fi Hizb al-Rahim, (Mesir: Mustafa al-Babi al-Halabi, t.th.), h.125
} 
bertentangan dengan syari'at, hal ini dikarenakan adanya sisi penglihatan yang berbeda terhadap metode amalan tasawuf. ${ }^{73}$ Ungkapan dan penjelasan di atas, secara tersirat menjelaskan bahwa peraturan mengosongkan amalan tarikat, tidak berarti tarikat yang lain salah, akan tetapi, hal ini dimaksudkan supaya murid lebih terkonsentrasi pada satu ajaran.

2. Wirid Wazifah ${ }^{74}$

Wirid Wazifah adalah amalan yang dilakasanakan satu kali dalam sehari semalam, dengan praktek wirid sebagai berikut

a. Muqaddimah (pendahuluan)

b. Membaca istigfar (minta ampunan Allah ) Astagfirullah al-'Adzim allazi la ilaha illa huwa al-hayyu al-qayyum, sebanyak 30 kali.

c. Membaca zikr (zikir) la ilaha illa Allah sebanyak 100 kali.

d. Membaca salawat fatih sebanyak 50 kali. Bunyi salawat fatih tersebut : allahumma shalli ....

e. Membaca salawat jauharat al-kamal sebanyak 12 kali.

f. Khatimah (penutup).

Bunyi salawat jauharat al-kamal, sebagai berikut:

Allahumma.....

Salawat jauharat al-kamal bersifat menjelaskan atau menafsirkan kalimat yang terdapat dalam salawat fatih, yakni kalimat "al-fatih lima ugliq". Salawat tersebut mengungkapkan sifat-sifat Nabi Muhammad saw., antara lain ; Nabi Muhammad

\footnotetext{
${ }^{73}$ Umar al- Futi, op.cit., h. 105

${ }^{74}$ Wazifah (bahasa arab) berasal dari kata wazafa yang berarti menetapkan. Sedangkan wazifah berarti tugas atau fungsi. Wirid Wazifah berarti ketetapan wirid bagi setiap murid Ahmad al-Tijani
} 
saw. sebagai hakikat rahmat dari sifat-sifat Tuhan yang merupakan pusat pengetahuan; sebagai al-haqiqat almuhammadiyyah yang memiliki sifat-sifat Tuhan yang mengalir dan menyinari keseluruh alam; sebagai wujud yang paling sempurna.

Menurut Ahmad al-Tijani sebagaimana diungkapkan dalam Jawahir al-Ma'ani, pada dasarnya Nur (cahaya) Sayyidina Muhammad saw adalah awal segala sesuatu yang diciptakan Allah swt, ${ }^{75}$ dan melalui perantara nur inilah terjadi seluruh alam. $^{76}$ Juga dikatakan bahwa nur Nabi Muhammad saw telah wujud sebelum makhluk lain ada, bahkan nur ini merupakan sumber semua nabi sebelum Nabi Muhammad saw, nur tersebut dimaksudkan adalah hakikat muhammad (al-haqiqat almuhammadiyyah $)^{77}$

Pendapat Ahmad al-Tijani di atas berkesesuaian dengan teori al-Hallaj (w.309 H) yang mengatakan bahwa cahaya muhammad (al-nur al-muhammady) merupakan wujud terdahulu. Yaitu cahaya azali yang ada sebelum adanya sesuatu. Cahaya terdahulu itu merupakan landasan semua nabi sebelum Nabi Muhammad saw. Wujud Nabi Muhammad saw dalam pengertian al-haqiqat al-muhammadiyyah atau nur sayyidina Muhammad adalah azali (terdahulu), sebab ia ada sebelum makhluk-makhluk lain ada, bahkan makhluk-makhluk lain muncul daripadanya.

\footnotetext{
${ }^{75}$ Menurut Ahmad al-Tijani, pemahaman tersebut berdasarkan sabda Nabi Muhammad saw, yaitu : "awwalu ma khalaqa Allahu nuri" (awal segala sesuatu yang diciptaakn Allah aadalah Nur aku). Lihat Ali Harazim, op.cit., juz I, h. 130. Menurut Ibn Taimiyah, sanad hadis ini tidak dikenal di kalangan ahli hadis. Oleh sebab itu ia memandangnya bukan hadis. Namun dalam kitab tasawuf dikatagorikan sebagai hadis. Dalam tradisi sufi banyak hadis-hadis yang tidak dikenal di kalangan ahli hadis. Namun mereka melihatnya melalui kasyf.

${ }^{76}$ Ali Harazim, op.cit., Juz I, h. 121. Lihat juga Sayyid Ubaidah, op.cit., h. 160.

${ }^{77}$ Ibid., h. 95-96.
} 
Sejalan dengan pendapat di atas, ibn Arabi (w. $560 \mathrm{H}$ ) mengemukakan teori manusia sempurna (al-insan al-kamil) atau hakikat Muhammad (al-haqiqat al-muhammadiyyah) yang didasarkan pada kesatuaan wujudnya (wahdat al-wujud). Manusia sempurna adalah alam seluruhnya. Allah ingin melihat substansinya dalam alam yang meliputi seluruh hal yang ada, menurutnya kemunculan manusia sempurna adalah esensi cermin alam. Tegaknya alam justru oleh manusia sempurna dan alam ini akan tetap terpelihara selama manusia sempurna masih ada. Manusia sempurna atau hakikat Muhammad adalah sumber seluruh hukum, kenabian, semua wali atau individu-individu manusia sempurna (yaitu para sufi yang wali). ${ }^{78}$

Pendapat Ahmad al-Tijani tentang nur Sayyidina Muhammad atau al-haqiqat al-muhammadiyyah nampaknya dipengaruhi oleh al-Hallaj melalui Ibn Arabi, hal ini karena Ahmad al-Tijani banyak memperlajari kitab Futuhat al-makiyyah karya Ibn Arabi, buktinya di dalam Jawahir al-ma'ani banyak dikutip pendapat-pendapat Ibn Arabi. Dalam menafsirkan "alfatih lima ugliq" (pembuka segala yang tertutup), Ahmad alTijani mengatakan bahwa Nabi Muhammad saw. merupakan pembuka pintu rahmat Allah, kalaulah Allah tidak menciptakan Nabi Muhammad saw. maka Allah tidak membukakan pintu rahmat-Nya kepada makhluk-Nya, demikian juga ia merupakan pintu wujud makhluk yang ada. ${ }^{79} \mathrm{Hal}$ ini menurut Ahmad alTijani didasarkan pada hadis Nabi saw. yang berbunyi : "kuntu nabiyyan wa adam baina al-ma'i wa al-turab". ${ }^{80}$ (Saya telah menjadi Nabi ketika Adam as, masih berada antara air dan tanah). Hadis ini menunjukkan bahwa Nabi Muhammad saw

\footnotetext{
${ }^{78}$ Ibn Arabi, Fusus al-Hikam, (Kairo: Mustafa l-Babi al-Halabi, 1946) h. 129

${ }^{79}$ Ali Harazim, op.cit.,juz I, h. 122. Lihat juga Sayyid Ubaidah, op.cit., h. 154.

${ }^{80}$ Al-Tirmidzi, op.cit., h. 508.
} 
dalam kapasitasnya sebagai haqiqat al-muhammadiyyah, telah diangkat menjadi nabi sebelum lahir jasad beliau. ${ }^{81}$

Ungkapan sifat-sifat Nabi Muhammad saw di atas merupakan penjelasan konsep yang telah dikemukakan sufi-sufi terdahulu, terutama dalam mensifati pemahaman mereka terhadap haqiqat (hakikat) muhammad yang azali (terdahulu). Sungguhpun Ahmad al-Tijani tidak secara langsung mengungkapkan bahwa wujud muhammad mempunyai dua hakikat (haqiqat), sebagaimana dikemukakan oleh al-Halllaj dan Ibn 'Arabi. Namun secara umum, tidak dapat dibantah bahwa ia sependapat, bahkan ia menjelaskan konsep dua sufi besar tersebut.

Apabila dalam wirid lazimah aspek bacaan istigfar dengan berbagai ketentuannya mendapat tekanan yang sangat besar, maka dalam wirid wazifah penekanan lebih ditujukan kepada aspek bacaan salawat. Tidaklah mengherankan, sebab dalam wirid ini terdapat dua bentuk salawat yang tidak terdapat dalam wirid lazimah. Kedua bentuk salawat dimaksud adalah salawat al-fatih dan salawat jauharat al-kamal.

Kaitannya dengan bacaan salawat dalam wirid wazifah terdapat dua aspek penekanan yaitu aspek syukur ${ }^{82}$ yang didasarkan pada posisi Nabi Muhammad saw. sebagai al-fatih lima ugliq dan aspek mahabbah (cinta). Aspek syukur dengan membaca salawat bagi murid mempunyai dasar mahabbah terhadap Nabi Muhammad saw dibuktikan dalam amalan salawat, sebab pada dasarnya mahabbah itu sendiri mempunyai arti yang sangat besar dalam membina hubungan yang berkesinambungan dengan Nabi Muhamad saw.

Ahmad al-Tijani mengemukakan, bahwa mahabbah itu sendiri harus diikuti dengan mengamalkam sunnahnya,

${ }^{81}$ Ali Harazim, op.cit., juz II, h. 266.

${ }^{82}$ Ali Harazim, op.cit., juz II , h.126 
petunjuknya, dan mengikuti seluruh perjalanan hidupnya. Dalam Jawahir al-ma'ani dikatakan : "mahabbah kepada Allah harus dibuktikan dengan mengikuti kekasih -Nya (Nabi Muhammad saw) secara lahir dan bathin, membenarkan seluruh beritanya, taat terhadap seluruh perintahnya, memenuhi segala panggilannya. Mahabbah tersebut dimaksudkan mencintai rasul dijadikan sebagai obat hati sanubari, istirahatnya jiwa, dan merupakan kenikmatan ruh. $^{83}$ Membaca salawat kepada Nabi saw pada dasarnya mengandung makna cinta, mengagungkan, dan diikuti dengan melaksanakan sunnah secara total. Mengikuti rasul merupakan tanda mahabbah seseorang terhadap Tuhannya.

Tanda-tanda bahwa murid yang bersangkutan mencintai Rasul saw. (mahabbah al-rasul) menurut Ahmad al-Tijani adalah "Ia selalu rindu untuk bertemu dengan al-mahbub (Nabi Muhammad saw), senantiasa mengagungkannya ketika disebut namanya dengan menampakkan perasaan $k h u d u$ ' (rendah hati) dan khusu'(khusuk), selalu mencintai Al-qur'an, sebab ia adalah firman Allah yang disampaikan melalui al-mahbub, dan terus menerus mempelajari sunnahnya. Jadi konsep syukur dan mahabbah pada intinya harus dibuktikan dengan kecintaan terhadap segala sesuatu yang datang dari Nabi Muhammad saw melalui pengamalan terhadap segala sunnahnya. ${ }^{84}$

Aspek yang ditekankan dalam wirid wazifah adalah bacaan salawat kepada Nabi Muhammad saw dengan pengamalan terhadap sunnahnya. Upaya ini pada dasarnya mempunyai maksud peningkatan maqam, yakni dari maqam taubat menuju maqam istiqamah (peringkat teguh pendirian), maksudnya teguh dalam melaksanakan sunnah, dengan harapan tertanamnya nilainilai ittiba' (mengikuti) pada Rasul dalam diri murid, untuk bisa

\footnotetext{
${ }^{83} \mathrm{Ibid}$, h.201-213

${ }^{84}$ Ibid, h. 211 dan 202
} 
naik ke maqam selanjutnya. Dengan demikian pengamalan terhadap sunnah merupakan kunci keberhasilan murid yang bersangkutan dalam menjalani maqamnya, yakni maqam istiqamah.

Selain itu bacaan salawat dalam wirid wazifah mempunyai fungsi membina dan mengarahkan murid untuk sampai pada tingkat bisa "menghadirkan" Rasulullah saw. Kaifiyat (cara) membaca salawat ini ada ketentuan khusus dari tarikat Tijaniyah, yaitu murid harus menundukkan kepala disertai perasaan khudu' (rendah hati) dan khusyu' (khusuk), sampai pada tingkat "menghadirkan" Rasulullah saw. ${ }^{85}$ karena menurut Ahmad alTijani orang yang mencapai tingkat ma'rifah kepada Allah harus terlebih dahulu melakukan pendekatan dengan Rasulullah saw.

3. Wirid Hailalah (membaca la ilaha illa Allah)

Wirid hailalah, dilaksanakan satu kali dalam seminggu, yaitu pada setiap hari Jum'at setelah sembahyang Ashar dengan cara membaca zikir la ilaha illa Allah yang dilaksanakan secara berjamaah sampai datangnya waktu magrib. ${ }^{86}$ Pengalokasian waktu hailalah pada hari Jum'at setelah ashar berkaitan dengan waktu mustajab (saat ijabah).

Apabila wirid hailalah dilaksanakan munfarid (sendirian) karena ada halangan, maka harus dilaksanakan dengan ketentuan membaca zikr sebanyak 1600 kali atau minimal 1000 kali, dan tidak diharuskan sampai datangnya waktu magrib. ${ }^{87}$

Apabila dalam wirid lazimah ditekankan untuk membersihkan diri dari segala bentuk kotoran maksiat dengan modal dasar amalan istigfar, kemudian membina hubungan dengan rasul dengan jalan mengamalkan segenap sunnahnya

\footnotetext{
${ }^{85}$ Muhammad Ibn Abdillah, op.cit., h. 96

${ }^{86}$ Ali Harazim, op.cit., juz I, h. 105

${ }^{87}$ Muhammad Ibn Abdillah, op.cit., h. 70. Lihat juga Sayyid Ubaidah, op.cit., h. 60.
} 
bahkan sampai pada tingkat bisa "berhubungan" dengan Rasul saw. melalui amalan dasar salawat, sebagaimana terdapat dalam wirid wazifah, maka dalam wirid hailalah, penekanannya ditujukan terhadap amalan zikr. Dalam wirid hailalah amalan zikr mempunyai fungsi menggerakkan ruh untuk membangun tauhid zauqi (tauhid rasa).

Dalam ajaran tasawuf, pengertian tauhid (mengesakan Tuhan) bukan sekadar pengakuan tentang keesaan Tuhan melalui pendekatan dalil naqli (al-Qur'an dan hadis) dan aqli (akal) saja, melainkan dengan cara membebaskan diri dari ketergantungan dan hasrat terhadap selain Allah. Langkah-langkah yang mesti ditempuh untuk membangun tauhid zauqi (tauhid rasa), hendaknya murid menghilangkan dan menghapuskan hasrat terhadap selain Allah. Maksudnya agar murid dapat berkonsentrasi menuju Tuhan. Untuk itu murid harus benar-benar berpaling dan menghilangkan dari pikiran dan perasaannya semua hal yang bersifat kemakhlukan.

Seseorang akan meraih tauhid zauqi apabila segala pikirannya khusus terhadap keesaan Allah (muwahhid), pikirannya tidak menampakkan dirinya, yaitu dengan peniadaan semua sekutu terhadap makhluk Allah, dibarengi dengan pelaksanaan semua perintah-Nya, baik secara lahir maupun batin. Tauhid zauqi yang "sempurna" akan tercapai apabila perhatian muwahhid pada dirinya telah hilang (fana'/sirna). Tegasnya tingkat kesempurnaan tauhid akan dicapai apabila muwahhid sudah terserap atau menyatu kedalam cahaya Tuhan. ${ }^{88}$ Dalam mengungkapkan tauhid ini, Ahmad al-Tijani menggambarkan melalui ungkapan tauhid li nafsih bi nafsih 'an nafsih (untuk Allah, dengan Allah, dari Allah).

\footnotetext{
${ }^{88}$ Ali Harazim, Op.cit., h. 96
} 
Amalan zikr dalam hailalah mendidik murid senantiasa dekat dengan Allah secara lahir dan batin, sehingga yang digoreskan didalam hati dan yang diucapkan oleh lisan yakni $z i k r$, berjalan seiring terus menerus ${ }^{89}$ dan bersifat reflek. Hal ini dimaksudkan untuk menolak setiap goresan jelek dalam pikiran. Sehingga menghasilkan pikiran yang jernih, bersih dari goresangoresan selain Allah. Amalan zikr pada dasarnya merupakan dasar-dasar amalan yang harus dikembangkan oleh para murid untuk menata maqamat sampai mencapai derajat kewalian.

Dari paparan di atas menunjukan bahwa para wali (awliya) mempunyai derajat yang bertingkat-tingkat sesuai dengan maqam yang sedang dilaluinya dan sebagai indikatornya Tuhan melepaskannya dari ikatan duniawi dan ia dibebaskan dari godaan-godan nafsu, dan dia menempatkan masing-masing pada derajat yang khusus sesuai dengan maqamnya, dan membukakan mereka pintu rahasia-Nya. Ahmad al-Tijani menyatakan bahwa, kewalian merupakan prinsip dan dasar tasawuf serta pengetahuan tentang Tuhan bertumpu pada kewalian ${ }^{90}$

Paparan di atas, mengantarkan kepada suatu pemahaman bahwa tasawuf adalah disiplin melaksanakan taqarrub kepada Allah. Sedangkan cara atau metodanya disebut tarikat, sebab yang dimaksud dengan tarikat sebagaimana telah diungkapkan adalah jalan menuju Allah swt. Ada juga yang mengatakan bahwa tarikat disiplin dalam melaksanakan perintah-Nya dan menjauhi larangan-Nya disertai berpaling dari daya tarik kesenangan nafsu syahwat. Orang yang demikianlah yang sudah sampai pada maqam ma'rifah. Hal ini berarti bahwa kewalian adalah inti dari tasawuf. Karena yang dimaksud wali adalah seseorang yang disiplin melakukan ibadah (taqarrub) melalui

\footnotetext{
${ }^{89}$ Ibid., h.114

${ }^{90}$ Ibid., juz II, h. 105
} 
tahapan maqamat sampai pada tingkat mengetahui rahasiarahasia Tuhan, bahkan menurut sebagian sufi sampai pada tingkat ittihad (penyatuan). Proses kewalian harus dibina melalui peniadaan segala hasrat baik yang bersifat duniawi maupun ukhrawi. Kaitannya dengan sikap dan sifat kewalian Ahmad alTijani mengatakan bahwa tasawuf adalah ilmu yang terpaut pada kalbu para wali karena mengamalkan al-Qur'an dan sunnah.

Tiga bentuk amalan wirid yang terdapat dalam tarikat Tijaniyah, yaitu wirid lazimah, wirid wazifah dan wirid hailalah, secara umum baru merupakan pemahaman nilai-nilai taubat, istiqamah, zuhd dan taqwa. Maqamat ini merupakan dasar pengembangan nilai-nilai yang terkandung dalam amalan $z i k r$. Maqamat inilah yang merupakan tahap pertama (awwal jur'ah) dari tauhid zauqi (tauhid rasa)

Perjalanan para sufi untuk bisa memantapkan bangunan tauhid zauqi, wusul (sampai) dengan Allah, atau maqam ma'rifah, bahkan maqam kewalian, bukanlah merupakan perjalanan yang pendek dan mudah, tetapi merupakan perjalanan panjang penuh tantangan. Atas dasar ini Ahmad al-Tijani memberikan peringatan kepada murid tarikat Tijaniyah, bahwa untuk bisa wusul kepada Allah, hendaklah tidak merasa cukup dengan amalan pokok yang terdapat dalam ajaran tarikat saja, tetapi hendaklah ditopang dengan amalan ikhtiyariyah (pilihan) yang terdapat dalam tarikat Tijaniyah, seperti do'a, salawat, dan hizb. Selain itu murid Tijaniyah tidak boleh melakukan ziarah kepada wali-wali Allah. ${ }^{91}$ Maksudnya dilarang ziarah apabila menimbulkan pertalian (ta'alluq) dengan selain Syekh Ahmad alTijani. Sedangkan yang dilarang adalah ziarah dengan tujuan mengambil amalan-amalan tertentu, sebab mengambil ajaran wirid dari selain yang terdapat didalam tarikat Tijaniyah, akan 
membawa dampak yang kurang menguntungkan bagi murid, yaitu memperlambat proses tercapainya wusul pada Allah.

Ikhlas adalah menghilangkan segala sesuatu selain Allah, menghilangkan goresan hati dari keinginan terhadap nikmatnikmat yang dijanjikan Allah, demikian juga sikap menghindar dari siksa Allah. Sebab pada dasarnya, nikmat dan siksa itu sendiri termasuk dalam katagori "selain Allah". Melaksanakan ibadah dengan dasar keinginan memperoleh nikmat surga dan menghindar dari siksa neraka, termasuk dalam katagori syirik alagrad (musyrik tujuan). Amalan zikr yang terdapat dalam wirid hailalah, harus mampu menciptakan kesatuan arah dalam melaksanakan ibadah, yakni hanya tertuju pada Allah, dengan kata lain harus mampu menciptakan nilai-nilai ikhlas.

Kaitannya dengan pengamalan nilai-nilai ikhlas, murid harus menempatkan Allah dihatinya, tidak ada tempat buat selain Allah, hatinya harus diisi penuh dengan zikr pada Allah (alwahid al-haq) dan murid harus bersikap tawakkul. ${ }^{92}$ Hakikat tawakkul adalah seseorang harus menjadi milik Tuhan, dan Tuhan harus menjadi miliknya. Ahmad al-Tijani memberikan pengertian ini dengan seseorang yang bertawakkul, berarti ia menjadi sepenuhnya sebagai milik Tuhan, apapun kehendak Tuhan terhadapnya, dia tidak akan mempersoalkannya, sebab ia kepunyaan-Nya. Mengenai perlunya kepasrahan diri pada kehendak Tuhan, hal ini dimaksudkan agar murid puas dengan Tuhan dalam segala keadaan. ${ }^{93}$ Faham tawakkul ini dimaksudkan agar murid terikat sepenuhnya hanya kepada Allah. Sehingga nilai zikr menyatu dalam dirinya.

Apabila murid melaksanakan nilai-nilai tawakkul secara utuh, sehingga nilai zikr telah menyatu antara apa yang

\footnotetext{
${ }^{92}$ Ibid., h. 129

${ }^{93}$ Ibid., h. 13, Lihat juga Sayyid Ubaidah, op.cit., h. 85.
} 
digoreskan dalam hatinya dengan segenap perbuatannya, maka dalam diri murid akan muncul sikap rida'. Pada posisi ini, murid telah terikat dengan Tuhan secara utuh. Sebab yang dimaksud dengan rida' ialah menerima dengan tenang semua ketentuan yang datang dari Allah. Kemudian secara bulat memasrahkan dirinya kepada apa yang menjaadi kehendak Tuhan. semua yang terjadi dan akan terjadi pada diri pribadinya diterima dengan segala senang hati, bahkan ia merasa senang menerima malapetaka sebagaimana ia merasa senang menerima nikmat. ${ }^{94}$ Hal ini disebabkan oleh kesadarannya bahwa semua itu datang dari Allah semata. Semua yang berasal dari-Nya adalah bermanfaat dan hanya untuk kebaikan manusia. Dengan demikian segala yang terjadi pada dirinya disambut dengan hati terbuka bahkan dengan rasa bahagia, walaupun hal yang datang itu berupa bencana. Ketika dalam diri murid telah tertanam sikap rida' (rela) yakni menerima dengan rela segala ketentuan Allah, berarti murid telah terikat dengan Tuhan secara utuh.

Ketika dalam diri murid sudah tertanam nilai tuma'ninah secara utuh, selanjutnya akan muncul mahabbah (cinta). Mahabbah adalah penyesuaian sifat-sifat dan akhlak-akhlak ilahiyah kedalam diri yang mencintai. Bila seorang murid cinta kepada Tuhan, maka perhatiannya hanya akan tertuju pada-Nya, dalam arti ia selalu berusaha menyesuaikan diri dengan akhlak ilahiyah. Hal ini seperti yang diungkapkan oleh Ahmad al-Tijani : "mahabbah adalah segala penghapusan sifat-sifat yang mencintai dan penetapan yang dicintai (Tuhan)",95

Selanjutnya Ahmad al-Tijani mengatakan bahwa apabila seseorang telah dipenuhi oleh rasa cinta kepada Tuhannya, maka berarti secara bulat hatinya telah diserahkan kepada-Nya,

\footnotetext{
${ }^{94} I$ Ibid., juz II, h. 121

${ }^{95}$ Ibid, juz II, h. 164
} 
sehingga tidak ada satupun yang diharapkannya selain Allah. Seseorang yang selalu mengingat Tuhannya, sampai pada tingkat Tuhan menghilangkan tabir yang menghalangi dan menutupi-Nya. Mahabbah pada tingkat ini hanya akan didapat oleh orang yang terbuka hijab (tabir). ${ }^{96}$ Kecintaan Tuhan terkandung dalam rahmat-Nya yang dilimpahkan kepada umat manusia. Cinta Tuhan terkandung dalam kemurahan-Nya kepada manusia, yaitu dengan memalingkan manusia dari berbagai pemikiran tentang segala sesuatu yang lain kecualli Tuhan, melimpahkan manusia dengan maqam yang tinggi melalui tajalli-Nya (penampakan lahir). Mahabbah hanya dapat dimanifestasikan dalam bentuk ketaatan seorang hamba untuk mengerjakan perintah Tuhannya setiap saat, berikut penyesuaian dengan akhlaknya, sampai pada tingkat Tuhan tajalli pada dirinya. Tandanya adalah murid dawam melaksanakan zikr tanpa ada paksaan. Dengan demikian segala sesuatu selain Allah tidak terlintas dalam hatinya. ${ }^{97}$

Pada maqam ini nilai zikr mengarahkan murid untuk terikat penuh kepada Allah, sebab maqam ini merupakan gerbang menuju tahapan ma'rifah (mengenal Allah). Apabila murid sudah mapan pada tahapan mahabbah, maka ia akan meningkat menuju maqam muraqabah, "terbukanya hijab (tabir) untuk melihat rahasia-rahasia Allah".98 Selanjutnya, apabila murid berada pada maqam muraqabah ini, ia harus memperhatikan halhal sebagai berikut :

Pertama, melaksanakan seluruh hak-hak Allah, lahir batin; Kedua, senantiasa mengarahkan ruh untuk berpaling dari selain Allah; Ketiga, hati-hati terhadap isyarat-isyarat ruhani

\footnotetext{
${ }^{96}$ Ibid., juz II, h. 94.

${ }^{97}$ Ibid., juz I, h. 140

${ }^{98}$ Ibid.,juz II, h, 84
} 
yang datang, sebab hal itu akan membelotkan tujuan yang sebenarnya; dan keempat, merahasiakan apa-apa yang tampak dari rahasia-rahasia yang didapat. ${ }^{99}$ Apabila murid telah mapan pada maqam muraqabah, maka selanjutnya ia akan meningkat ke maqam musyahadah, yaitu "melihat rahasia-rahasia Allah (alhaqaiq) tanpa hijab (tabir) dengan telaahan diatas maqam muraqabah. Sebab pada posisi ini ruh telah suci dan bersih dari segala pengaruh wahm (dugaan), sehingga tidak ada sedikitpun yang tersisa selain rahasia ketuhanan, al-haq tajalli pada cermin ruh tanpa batas, tanpa tasybih (keserupaan).

Telah dikatakan, ketika murid memasuki maqam muraqabah, berarti ia telah melihat rahasia Allah untuk selanjutnya ia memasuki maqam musyahadah yaitu melihat Allah tanpa hijab. Ketika murid berada dimaqam muraqabah dan musyahadah, dalam hal ini berarti murid telah memasuki maqam atau lingkup ma'rifah. Ma'rifah menurut Ahmad alTijani adalah "pengetahuan akan adanya keagungan Tuhan, melalui limpahan anwar al-qudsiah (cahaya suci). ${ }^{101} \mathrm{Ma}$ 'rifah itu milik Tuhan, dan hanya diperoleh melalui limpahan rahmat-Nya. Ma'rifah hanya akan dilimpahkan oleh Tuhan kepada sufi yang dikehendaki-Nya. Tidak sembarang orang dapat mencapai atau menerima ma'rifah, hanya mereka yang terpilih saja yang mampu mendapatkannya. Tuhan yang memilih mereka untuk menerima anugrah dan memilih mereka untuk-Nya dan memberi mereka cinta-Nya. ${ }^{102}$ Anugrah yang diberikan Tuhan adalah merupakan rahmat yang dilimpahkan atas kehendak Tuhan sendiri. Ma'rifah yang dicapai hamba-hamba pilihan merupakan pengetahuan tentang Tuhan yang sempurna. Sesungguhnya

\footnotetext{
${ }^{99}$ Sayyid Ubadah, op.cit., h, 123.

${ }^{100}$ Ibid., h. 107

${ }_{101}$ Ali Harazim, op.cit., h. 86 dan 112.

${ }^{102}$ Ibid.,juz II, h. 87.
} 
ma'rifah yang sempurna tidak akan pernah ada. Karena keterbatasan manusia itu sendiri, sedangkan Tuhan merupakan zat yang tak terbatas (la ghayah wa la nihayah) oleh sebab itu, tidak mungkin sesuatu yang terbatas dapat mengetahui yang tidak terbatas dengan segala kesempurnaanya. ${ }^{103}$

Ungkapan diatas menunjukkan bahwa sekalipun objek ma'rifah adalah satu, namun ia memiliki tingkatan rendah dan tingkatan tinggi. Itulah sebabnya orang-orang pilihan-Nya dapat mencapai tingkat tertinggi ma'rifah. Sekalipun mereka tidak pernah dapat mencapai akhir dari ma'rifah itu. Lantaran objeknya, merupakan sesuatu yang tak terbatas. Atau dengan kata lain manusia tidak akan pernah dapat memahami Dia sepenuhnya lantaran Dia adalah Zat Maha Sempurna. ${ }^{104}$ Ma'rifah itu bagaikan laut yang tak bertepi, yang kedalaman dan keluasannya tak dapat diduga, sehingga tak seorangpun diantara manusia dapat memahami keagungan dan kebesaran Tuhan secara utuh.

Dalam rangka menjalani maqam-maqam seperti yang dijelaskan pada bagian lalu, maka menurut Ahmad al-Tijani ada satu hal yang perlu diperhatikan yaitu senantiasa harus mengikatkan diri dengan ajaran-ajaran syari'at lahir bathin. Hendaklah sufi senantiasa tenggelam dalam lautan cahaya haqiqat (an yastagriqa fi anwari al-haqiqah) dan secara lahir senantiasa mengamalkan syari'at (wa ya'malu bi al-syari'ah zhahira) ${ }^{105}$

Puncak perjalanan tarbiyah ruhani tarikat Tijaniyah adalah maqam muraqabah, musyahadah dan ma'rifah yang diliputi fana' al-'fana'; yakni suatu kondisi ia akan kehilangan kesadaran terhadap segala sesuatu di sekitarnya, walaupun ia sendiri berada

\footnotetext{
${ }^{103}$ Ibid., h. 205

${ }^{104}$ Ibid., h. 70.

${ }^{105}$ Ibid., h. 101
} 
di lingkungan tersebut. Hal ini disebabkan tajalli Tuhan yang berpengaruh langsung pada dirinya. Gambaran puncak perjalanan ruhani tarikat Tijaniyah ini merupakan keadaan sakr yang dialami oleh setiap sufi ketika mencapai puncak pengalaman tasawufnya, setelah itu ia akan kembali pada kesadaran (sahw) atau hidup setelah mati (al-hayat ba'da almaut). Ia akan memperoleh kembali kemampuannya dalam membedakan sesuatu, ia akan kembali kekehidupan normal sebagai seorang muslim biasa. ${ }^{106}$

Setelah kehilangan kesadaran seorang sufi akan kembali kepada kondisi awalnya sebagaimana sebelum mengalami fana' al-fana'. Hal ini terjadi semata-mata atas kehendak Tuhan. Tuhanlah yang telah mengembalikan sufi tersebut pada sifatsifatnya semula. Ini berarti fana adalah karunia Allah, dan bukan merupakan hal yang bisa diusahakan (gair al-muktasab). ${ }^{107}$

Seorang sufi yang telah kembali menjalani kehidupannya sebagaimana layaknya sorang muslim, cahaya ma'rifah yang diperolehnya tetap menyinari dirinya. Hal ini termanifestasikan dalam setiap gerakan dan ucapannya. Karena cahaya ketuhanan yang telah didapatkannya, menyebabkan ia memiliki keistemewaan (karamah). Pada dasarnya karamah adalah anugrah Ilahi, bukan sesuatu yang diusahakan oleh manusia, sehingga usaha manusia tidak menjadi sebab bagi terwujudnya hal tersebut. Kesucian pengetahuan tentang Tuhan ( $m a$ 'rifah), merupakan dasar dari semua karamah yang dianugrahkan oleh Allah kepada hamba-Nya. Karamah hanya bisa ditampilkan oleh orang yang sudah sampai pada maqam tertentu, misalnya maqam ma'rifah ${ }^{108}$

\footnotetext{
${ }^{106}$ Ibid., juz II, h.13

${ }^{107}$ Ibid., h. 80 lihat juga Sayyid Ubaidah,op.cit., h. 105.

${ }^{108}$ Ibid., h. 98.
} 
Demikianlah ajaran tasawuf Ahmad al-Tijani. Lewat ajarannya tentang proses tabiyah ruhiah (pendidikan ruhani) dapat dilihat tarikatnya sebagai upaya meraih posisi warasat alanbiya (pewaris para nabi). Tampilnya seorang sufi di tengah masyarakat merupakan bentuk lain dari ketaatannya pada Allah dan rasul-Nya. Peranan para sufi begitu penting dalam kehidupan masyarakat dalam melakukan dakwah Islam. Para sufi tidak selayaknya jika hanya mementingkan kontemplasi dan zikr, lantas mengabaikan masyarakat yang memerlukan bimbingan. 